NBER WORKING PAPER SERIES

ARE HEALTH INSURANCE MARKETS COMPETITIVE?

\author{
Leemore Dafny \\ Working Paper 14572 \\ http://www.nber.org/papers/w14572 \\ NATIONAL BUREAU OF ECONOMIC RESEARCH \\ 1050 Massachusetts Avenue \\ Cambridge, MA 02138 \\ December 2008
}

I am grateful for helpful suggestions by William Collins, David Cutler, James Dana, David Dranove, Mark Duggan, Pinelopi Goldberg, Vivian Ho, Katherine Ho, Julian Jamison, Ilyana Kuziemko, Mara Lederman, Jin Li, Niko Matouschek, Sean Nicholson, Mark Pauly, Scott Schaefer, Kosali Ilayperuma Simon, Allen Steinberg, Scott Stern, John Tatom, Robert Town, Dale Yamamoto, three anonymous referees, and seminar participants at Columbia, Duke, University of Maryland, Wharton, the NBER Summer Institute, the American Economic Association Annual Conference, the Northwestern University Law School, and the Searle Center Research Symposium on Insurance Markets and Regulation. Michael Loquercio, Tamra Hayford, and Subramaniam Ramanarayanan provided excellent research assistance. Funding from The Searle Center on Law, Regulation, and Economic Growth at the Northwestern University School of Law is gratefully acknowledged. The views expressed herein are those of the author(s) and do not necessarily reflect the views of the National Bureau of Economic Research.

NBER working papers are circulated for discussion and comment purposes. They have not been peerreviewed or been subject to the review by the NBER Board of Directors that accompanies official NBER publications.

(C) 2008 by Leemore Dafny. All rights reserved. Short sections of text, not to exceed two paragraphs, may be quoted without explicit permission provided that full credit, including $\odot$ notice, is given to the source. 
Are Health Insurance Markets Competitive?

Leemore Dafny

NBER Working Paper No. 14572

December 2008

JEL No. I1,IO,L1

\begin{abstract}
$\underline{\text { ABSTRACT }}$
Although the vast majority of Americans have private health insurance, researchers focus almost exclusively on public provision. Data on the private insurance sector is extremely difficult to obtain because health insurance contracts are complex, renegotiated annually, and not subject to reporting requirements. This study makes use of a privately-gathered national database of insurance contracts agreed upon by a sample of large, multisite employers between 1998 and 2005. To gauge the competitiveness of the group health insurance industry, I investigate whether health insurers charge higher premiums, ceteris paribus, to more profitable firms. I find they do, and this result is not driven by cross-sectional differences across firms or plans: firms with positive profit shocks subsequently face higher premium growth, even for the same healthplans. Moreover, this relationship is strongest in geographic markets served by a small number of insurance carriers. Further analysis suggests profits act to increase employers' switching costs, and insurers exploit this inelasticity where they have sufficient bargaining power. Given the rapid industry consolidation during the study period, these findings suggest healthcare insurers possess and exercise market power in an increasing number of geographic markets.
\end{abstract}

\author{
Leemore Dafny \\ Department of Management and Strategy \\ Kellogg School of Management \\ Northwestern University \\ 2001 Sheridan Road \\ Evanston, IL 60208-2001 \\ and NBER \\ 1-dafny@kellogg.northwestern.edu
}




\section{Are Health Insurance Markets Competitive?}

\section{Introduction}

The U.S. stands virtually alone among leading industrialized nations in its heavy and increasing reliance on the private insurance sector to intermediate healthcare for its residents. ${ }^{1}$ The assumption underlying this system is that fierce competition among private insurers yields more efficient outcomes, broadly writ (Enthoven 1978). However, a comprehensive survey on the state of competition in healthcare appearing in the 1999 Journal of Economic Perspectives concludes there is "little empirical evidence on competitive conduct by health insurance firms" (Gaynor and Haas-Wilson 1999). A 2004 report on the same by the Federal Trade Commission and the Department of Justice finds most experts believe the market is highly competitive (with the vocal exception of groups representing physicians), although new research on the subject is scarce and plagued by data and identification issues (see Scanlon et al. 2006 for a thorough review). ${ }^{2}$ Meanwhile, continued faith in competitive markets is manifest in the rapid increase in outsourcing of public insurance to the private sector (Duggan 2004; Duggan and Scott Morton 2008), as well as lax antitrust enforcement during two decades of extensive insurer consolidation. Only three combinations have been challenged by the Department of Justice, and these only in select markets. ${ }^{3}$

This study evaluates whether and where local insurance markets are competitive by testing for evidence of conduct that can only occur in imperfectly competitive markets. I

\footnotetext{
${ }^{1}$ Other notable exceptions include the Netherlands and Switzerland. Both countries require all individuals to purchase an approved healthplan from a private insurer.

2 "Improving Health Care: A Dose of Competition," A Report by the Federal Trade Commission and the Department of Justice (July 2004).

${ }^{3}$ These challenges were satisfied through consent decrees requiring divestiture in the markets with substantial overlap (Tucson and Boulder in the case of the UnitedHealth-PacifiCare merger in 2005; Houston and Dallas in the case of the Aetna-Prudential merger in 1999; and Las Vegas (Medicare Advantage plans only) in the case of the pending UnitedHealth-Sierra merger in 2008). Complaint, United States v. Aetna Inc., N0.3-99CV 1398-H, par. 19 and 20 (N.D. Tex. June 21, 1999); Final Consent Order, United States v. Aetna Inc., No.3-99CV 1398H (N.D. Tex. Dec. 7, 1999); Complaint, United States v. UnitedHealth Group Incorporated \& PacifiCare Health Systems, Inc., No. 1:05CV02436 (Dec. 19, 2005); Final Judgment, United States v. UnitedHealth Group Incorporated \& PacifiCare Health Systems, Inc., No. 1:05CV02436 (May 23, 2006). Final Judgment, United States V. UnitedHealth Group Incorporated and Sierra Health Services, Inc. No. 1:08CV00322.
} 
investigate whether firms with higher profits pay higher health insurance premiums, controlling as best as possible for differences in the plans selected, employee populations, and market conditions. The extent to which carriers are able to extract employer-specific rents offers a glimpse into competitive interactions in this important sector, as a competitive industry would be characterized by uniform pricing at cost. Although a "market conduct parameter" (i.e. a measure ranging from 0 to 1 , with 0 representing perfect competition and 1 monopoly) cannot be derived from estimates of rent extraction, differences in rent extraction across markets provide a useful indicator of the relative competitiveness of these markets.

Using a proprietary panel database on fully-insured healthplans offered by a sample of large, multi-site employers between 1998 and 2005, I find firms with positive profit shocks subsequently face larger premium increases, even for the same healthplans. Moreover, this increase is greatest in markets with the fewest insurance carriers (particularly 6 or fewer). Thus, a multi-site firm with high profits in a given year will subsequently face significantly higher health insurance premiums, but only at sites served by a concentrated insurance market. This result contradicts the leading alternative empirical explanation for my finding, namely that firms with high profits face higher premium increases because they increase benefits in dimensions I do not observe. (If this is the explanation, it should occur uniformly across all sites.)

To determine why insurance carriers are able to extract higher prices from profitable firms in concentrated insurance markets, I combine insights from field interviews with a model of bilateral bargaining, as large employers and insurers bargain annually over insurance contracts. The evidence suggests employers are reluctant to switch healthplans during "good times," i.e. profits increase willingness-to-pay for incumbent healthplans. The fact that, conditional on the same profit shock, premiums increase the most in markets served by a concentrated insurance industry could be explained by a) larger profit-induced increases in switching costs in concentrated insurance markets (i.e. there is more new rent to extract in these markets), b) greater bargaining (or market) power of insurers in these markets, or both. 
Returning to the data, I find no support for a): conditional on the same profit shock, firms in markets with fewer insurance carriers are more likely to switch carriers, suggesting switching costs do not increase more for profitable employers in these markets. Rather, it appears that the strong bargaining position of insurers in concentrated markets enables them to capture more of the extra surplus generated by profit shocks. (Because prices are ultimately the result of bargaining between employers and carriers, I generally use the term "rent extraction" in place of "price discrimination," which is typically reserved for settings in which the seller has commitment power, i.e., makes a single "take it or leave it" offer. This technicality notwithstanding, the practice I investigate is akin to first-degree price discrimination, in which the seller sets individual prices to extract the surplus of each buyer. In the case of a monopoly supplier, consumer surplus is wholly extracted. ${ }^{4}$ However, consumers retain some of the surplus in oligopoly settings (Spulber 1979; Armstrong 2006)..$\left.^{5}\right)$

The results offer the strongest evidence to date linking private health insurance premiums to the market power of insurers. The data also indicate that an increasing share of the population is purchasing coverage in the least-competitive markets. As of 2005, 23 percent of employees in my sample (which is representative of Americans covered by large firms, who account for roughly one-third of the insured nonelderly) received coverage in markets with 6 or fewer major carriers (in which rent extraction is most pronounced), up from 7 percent in $1998 .^{6}$ Due to recent consolidations, this figure is certainly greater today.

The findings complement recent work by Ho (2009) on the upstream bargaining between insurers and hospitals. Ho finds insurers in some markets successfully extract the rents of hospitals in their networks, and hospitals in turn differentiate themselves to avert

\footnotetext{
${ }^{4}$ The term "price discrimination" is typically reserved for settings in which the seller has commitment power, i.e., makes a single "take it or leave it" offer. For this reason, I use the term "rent extraction" in its stead, although the outcomes are the same.

${ }^{5}$ Spulber's model assumes each firm faces a downward-sloping residual demand curve and has the ability to perfectly discriminate. The pure-strategy Nash equilibrium is characterized by marginal-cost pricing; social surplus is therefore maximized. The residual demand curves become more elastic as competition increases, enabling consumers to capture an increasing share of surplus.

${ }^{6}$ The estimate of the number of insured nonelderly Americans covered by large firms (1000+ employees) was constructed by the author using estimates from the MEPS-IC (generously provided by Kosali Simon) and the Employee Benefits Research Institute (http://www.ebri.org/pdf/briefspdf/EBRI_IB_10a-20061.pdf).
} 
this. Collectively, the results suggest uncompetitive insurance markets may render ineffective recent efforts to contain public insurance costs by outsourcing healthplans to the private sector. Greater scrutiny of proposed consolidations in this sector may also be warranted, with particular attention to consolidations in markets with 6 or fewer major insurance carriers, and where switching costs of customers are high (e.g. if carriers are highly differentiated).

The paper proceeds in six sections. Section 2 provides background on the private health insurance industry and summarizes prior research. Section 3 describes the data in detail. Section 4 presents the main empirical analysis of rent extraction, together with key robustness checks and extensions. The model is described in Section 5, and analyses of healthplan switching are presented in Section 6. Section 7 concludes. 


\section{The U.S. Health Insurance Industry}

\subsection{Key Facts}

Figure 1 graphs the percentage of nonelderly Americans covered by private insurance from 1998-2005, separated by whether the coverage was employment-sponsored or individuallypurchased. Coverage from both sources declined slightly during the study period, but remained high, with 70 percent of the nonelderly obtaining insurance through the private sector in 2005. These figures understate the fraction of the nonelderly enrolled in private plans, as the majority of Medicaid beneficiaries are also enrolled in such plans (61 percent in 2005). Among the elderly, 95 percent are enrolled in Medicare, and nearly 13 percent of these received their care in 2005 through a private-sector Medicare Advantage plan. An additional 59 percent of the elderly had private supplementary coverage in $2005 .^{7}$

National statistics on private healthplans are available from the annual Employer Health Benefits survey, sponsored jointly by the Kaiser Family Foundation (KFF) and the Health Research and Educational Trust (HRET). ${ }^{8}$ This survey documents two key trends that are corroborated in my data. The first is the rapid increase in health insurance premiums. Figure 2 illustrates these increases for 1998-2005, based on figures for a family of four. Annual growth peaked at 13.9 percent in 2003, declining to a still-impressive 9.3 percent in 2005. These figures likely understate the trend as employers have adjusted to rising costs by reducing the generosity of benefits provided.

\footnotetext{
${ }^{7}$ Source: http://www.ebri.org/pdf/publications/books/databook/DB.Chapter\%2036.pdf. These figures do not reflect Medicare Part D, the prescription drug program introduced in 2006. Medicare Part D is administered entirely by the private sector and currently covers over 90 percent of Medicare beneficiaries. Many providers are pharmacy benefit management firms rather than health insurance carriers.

${ }^{8}$ The KFF/HRET survey randomly selects public and private employers to obtain national data about employersponsored health insurance; approximately 2000 employers respond each year. The data are not publicly available, nor is the sample designed to provide estimates at the market level. (KFF/HRET Employer Health Benefits 2006 Summary of Findings, document 7528). Since 1996, the Agency for Healthcare Research and Quality (AHRQ), a division of the Department of Health and Human Services, has also conducted an annual survey of employers in conjunction with the Medical Expenditure Panel Survey (MEPS). MEPS follows households over time, and the "Insurance Component" surveys employers of household members to gather data on healthplans. The micro data are available on-site at Census Research Centers to those with appropriate clearance, but they do not constitute an employer-plan-level panel. The most recent data available is for 2003.
} 
The second trend is the growth in the share of employees covered by self-insured rather than fully-insured plans (Figure 3). Many large employers choose to self-insure, outsourcing benefits management and/or claims administration but paying realized costs of care. Such employers can spread risk across large pools of enrollees, and may purchase stoploss insurance to limit their remaining exposure. Per ERISA (the Employee Retirement Act of 1974), these plans are also exempt from state regulations and state insurance premium taxes. According to the KFF/HRET survey, the share of large-firm employees enrolled in self-insured (as opposed to fully-insured) plans increased from 65 percent in 1998 to 82 percent in 2005. The increase among employees in all firms was much smaller: 50 to 54 percent. $^{9}$ According to Figure 2, premiums for fully-insured plans grew more quickly than average during this period.

My primary study sample includes only fully-insured plans. Reported "premiums" for self-insured plans are actually the employer's estimate of outlays for the average enrollee in the plan-year. These forecasts are used for budgeting purposes and to make decisions about enrollee contributions and stop-loss coverage. They are not directly comparable to premiums for fully-insured plans, which are set prospectively and always include risk premiums. Self-insured projections may include a partial risk premium if the employer purchases stop-loss coverage; whether stop-loss coverage is purchased is not captured in the data. I make use of the self-insured sample, however, for a number of supplemental analyses.

Premiums for fully-insured plans depend on the actuarial health risk of employees, details of plan design (e.g., copays, covered benefits, disease management programs), and general carrier characteristics (e.g., provider network, speed and accuracy of claims processing, reputation). The employers represented in my sample typically solicit bids every year from one or more healthplans in all of the markets in which they operate. Many use benefits consultants to serve as brokers in this process. According to the brokers I interviewed, after some back-and-forth on plan details (e.g. copays, drug formularies, etc.), a

\footnotetext{
${ }^{9}$ The rise in self-insurance, though beyond the scope of this paper, is an interesting subject for further research. Early work by Cooper and Simon (2007) reveals that firms are more likely to self-insure if they have multiple locations, a large number of workers, and high average wages.
} 
"final round" of negotiation over the premium for a fixed plan design may take place. The net result is that pricing of fully-insured healthplans is anything but transparent, rendering the setting ripe for differential pricing across employer groups, ceteris paribus.

Contracts are signed 3 to 6 months prior to the start of the benefit year, which is generally the calendar year. Thus, an employer will typically begin selecting 2009 plans and rates by early 2008. To the extent that firm profits affect these agreements, the relevant profit figure will reflect data for 2007 (assuming data is available annually). ${ }^{10}$

\subsection{Prior Research}

A 2006 survey by Scanlon et al. finds 35 studies that investigate the impact of competition among health insurers on healthcare outcomes. Of these, 7 use some measure of premiums as an outcome. Most find a negative association between competition and premiums, but these studies suffer from serious data problems and identification issues. For example, one of the most careful studies (Wholey et al. 1995) relies on annual HMO-level data from 19881991. Premiums are estimated using average revenue per member per month, and the degree of competition faced by each HMO is estimated as a weighted average of the HMO penetration rate (the percent of insured individuals enrolled in an HMO) in all of the counties in which the HMO operates. PPOs are not considered, although in recent years courts have found HMOs and PPOs (as well as the variants in between) to be in the same product market. ${ }^{11}$ Summarizing the shortcomings in this literature at large, Scanlon et al. emphasize a poor correspondence between measures of market competition and actual competitive conditions. No studies address endogeneity of the concentration measures.

Two recent studies describe the high and increasing level of concentration in local insurance markets. Robinson (2004) uses a database of state regulatory filings to study state-

\footnotetext{
${ }^{10}$ Ginsburg et al. (2006) find evidence of a similar lag (18 months) between premiums reported by KFF/HRET and the cost of healthcare services (e.g., provider charges).

${ }^{11}$ The case law is summarized in "Improving Health Care: A Dose of Competition," ibid. Some cases in which separate markets for HMOs and PPOs have been rejected include Blue Cross \& Blue Shield v. Marshfield Clinic (65 F.3d 1406 ( th $^{\text {th }}$ ir. 1995)) and Ball Memorial Hospital v. Mutual Hospital Ins., Inc. (784 F. $2^{\text {nd }} 1325$ ( $7^{\text {th }}$ Cir. 1986)).
} 
level market structure over 2000-2003. By the end of his study period, nearly 40 states had a dominant carrier serving over one-third of the private market. Robinson also documents increases in premium revenues and operating margins. Of course, a causal link between concentration and premiums cannot be established through the coincidence of these trends. In addition, a commentary published alongside the piece states "an entire state is not a relevant geographic market, [hence] the existence of high HHIs in that state has no competitive (or probative significance)" (Hyman and Kovacic 2004). Robinson (2006) documents still higher state-level concentration figures. He also reports many insurers are targeting the public rather than the private sector for future growth.

The following section offers details on the high-quality, micro panel data that affords me the unique opportunity to examine the pricing of individual insurance contracts in the geographic markets actually utilized by insurers when negotiating rates. Importantly, the identification strategy relies on shocks to individual employers rather than shocks to market concentration.

\section{Data}

\subsection{The LEHID Data}

The primary dataset was provided on a confidential, limited-use basis by a major benefits consulting firm. ${ }^{12}$ The unit of observation is the plan-year. A plan is defined as a unique combination of an employer, geographic market, insurance carrier, and plan "type" (HMO, POS, PPO, and indemnity), e.g., Worldwide Widgets' CIGNA HMO in Phoenix, Arizona. The panel covers 1998-2005 (inclusive), and is unbalanced, with employers entering and exiting based on their relationship with the consulting firm, and specific healthplans appearing or disappearing when added or terminated, respectively. Note that participation is

\footnotetext{
${ }^{12}$ Employers of all sizes rely on external consultants when designing or purchasing benefits. Using a 1997 survey of 21,545 private employers, Marquis and Long (2000) find external consultants were employed by nearly half of the smallest firms ( $<25$ workers), and nearly two-thirds of the largest firms ( $>500$ workers). These findings suggest the firms engaging the services of my source are not unusual in this regard, strengthening the case for the generalizability of the results.
} 
complete for any year in which an employer is included in the sample (i.e., all plans offered by that employer are present). ${ }^{13}$

The full dataset includes observations from 776 employers and 139 geographic markets in the United States. The employers span a wide range of industries. The top 3 are manufacturing and financial institutions (tied for 13 percent of employers each), and consumer products ( 9 percent of employers). On average, 241 employers appear in the sample each year. The median employer operates in 47 geographic markets and insures 9,670 active employees (retirees are not included in the data). The total number of employees represented in the sample averages 4.8 million per year. This figure does not include dependents, so the number of insured individuals represented by the survey is at least twice as large.

The geographic markets are defined by my source, and they represent the markets used by carriers and employers when negotiating rates. ${ }^{14}$ The markets are sometimes defined by state boundaries (e.g., Delaware), but more commonly by metropolitan areas (e.g., Kansas City (in Missouri and Kansas); Kentucky - Louisville, Lexington; Kentucky - except Louisville, Lexington). Figure 4 depicts the distribution of covered employees across the geographic markets. This distribution closely matches the distribution of privately-insured employees in these markets (estimated using county-level data from the Current Population Survey of March 2000). I will refer to the entire dataset by the acronym LEHID, for "Large Employer Health Insurance Dataset.”

\footnotetext{
${ }^{13}$ Some data scrubbing was necessary to ensure that the same ID was assigned to the same employer in every year. In the case of mergers, I create a new employer ID post-merger if both parties to the merger appear in the data separately in a prior year.

${ }^{14}$ Some carriers with a national presence will negotiate a single rate for all employees nationwide. See footnote 18 for a discussion of the implications of national pricing for the empirical analysis.
} 


\subsection{Study Sample}

The study sample is limited to fully-insured plans, for which premiums are determined prior to the start of the calendar year. ${ }^{15}$ The shift toward self-insured plans, highlighted in the KFF-HRET survey, is also apparent in LEHID: the proportion of employees enrolled in selfinsured plans increased from 58 to 76 percent between 1998 and 2005 . However, the total number of employees in fully-insured plans is still sizeable, averaging 1.6 million per year. ${ }^{16}$

I restrict the study sample to observations in geographic markets containing 20 or more distinct employers; that is, 20+ employers must offer a fully-insured (FI) choice in that market-year. This restriction is imposed to ensure accurate estimates of market structure, namely the total number of carriers serving a given geographic market. ${ }^{17}$ Only 3 percent of the fully-insured employees in my sample are dropped as a result of this restriction. Note this "LEHID-FI" sample is not the sample used for the regression analysis; that sample is further limited to plans for which profits of the associated employer can be obtained, and is described below.

\footnotetext{
${ }^{15}$ Self-insured plans report "premium equivalents," their predictions of costs per enrollee. These figures combine claim reimbursement, fees paid to carriers, and premiums for any stop-loss insurance.

${ }^{16}$ There is a good deal of overlap in the carriers serving self-insured and fully-insured groups. Among carriers serving more than 5 clients in LEHID, 57 percent have both fully-insured and self-insured plans, 41 percent have only fully-insured plans, and 2 percent have only self-insured plans. The smaller carriers ( $<=5$ clients) are more likely to be "pure plays," with 11,54, and 35 percent in these categories, respectively. Figures are tabulated using the carrier-year as the unit of observation.

${ }^{17}$ Attempts to estimate the number of carriers from alternative sources were unsuccessful. There are three potential sources of nationwide data for the study period: the Area Resource File, Interstudy (a private firm that compiles data on HMOs from state regulatory filings and various other sources), and web searches. The Area Resource File reports the number of HMOs headquartered in each county, clearly a very poor estimate of the desired variable. Interstudy provides information on the number and enrollment of HMOs by MSA. However, the Interstudy data is prohibitively expensive, excludes PPOs (which clearly compete with HMOs) in most years covered by this study, and has been roundly criticized for the methods it uses to attribute enrollment to different geographic areas (Scanlon et al 2006). Web searches also proved fruitless for several reasons. It is difficult to find time-series data for all markets, and to accurately capture the service area for each healthplan from the limited descriptions available online. Some insurers identified in these searches only serve particular market segments (e.g. the individual market or the Medicaid market), and this analysis is concerned with the large, fully-insured group market. Using the LEHID data itself (after applying the stringent $20+$ criterion) should yield the most accurate estimate of the number of carriers serving the customer segment and geographic market of interest.
} 
Figure 2 shows that premium growth in the LEHID-FI sample tracks the levels and trends published by KFF/HRET for FI plans fairly closely. This bodes well for the generalizability of the data and results. Figure 5 graphs the distribution of markets in the LEHID-FI sample by the number of carriers in the market. Data are presented separately for 1998, 2001, and 2005. The fraction of markets with fewer than 6 carriers increased from 10 to 35 percent over this period, while the fraction with more than 10 carriers decreased from 35 to 7 percent. The increase in concentration is also manifested in other measures such as the HHI and the 4-firm concentration ratio. However, these measures are more prone to measurement error due to the size and non-random nature of the sample.

The key independent variable for the analysis is the operating profit of employers. To obtain profit data, I created a crosswalk file to match LEHID-FI employers to companies appearing in Compustat, a database of financial statistics. The matches were identified by hand using company names, industry, locations, and number of employees. Extensive web research was required to verify matches for some observations, especially in cases of subsidiaries, non-U.S. firms, and firms involved in mergers and acquisitions. Profit is measured by the after-tax return on assets, defined as (earnings before extraordinary items + interest expense) / (gross assets (including depreciation/amortization)). ${ }^{18}$ Because Compustat is limited to large, publicly-traded firms, the LEHID FI-Compustat sample omits public-sector, nonprofit, and privately-held employers, as well as employers that do not appear in Compustat or lack data for the variables used to calculate operating profits. Of the 1678 employer-years in the LEHID FI sample, I am able to calculate lagged profit for 1151, or 69 percent of observations.

To control for local economic conditions and healthcare utilization trends, I add data on the unemployment rate (reported by the Bureau of Labor Statistics) and the Average Adjusted Per Capita Cost for Medicare enrollees (abbreviated AAPCC and reported by the Center for Medicare and Medicaid Services). Both measures are available at the county-year

\footnotetext{
${ }^{18}$ Compustat provides five alternative definitions of the after-tax return on gross assets. This definition corresponds most closely to the measure of firm profitability used in "Disappearing dividends: changing firm characteristics or lowering propensity to pay?" (Fama and French 2001). Results using the four other measures are extremely similar (see Online Appendix for details).
} 
level, whereas LEHID markets are defined by my source using 3-digit zipcodes. The correspondence is generally one-to-one in major metropolitan areas, where most LEHID employees are located. For those counties belonging to more than one market code, I assign weights in proportion to the share of the population in each market code accounted for by the zipcodes within that county.

Table 1 presents descriptive statistics for the LEHID FI-Compustat sample in each year. The key variables include annual premium, enrollment, demographic factor, plan design, plan type, and lagged profit. ${ }^{19}$ Annual premium combines employer and employee contributions, and is a per-employee average. It reflects both the features of the plan selected (e.g., insurance carrier, benefit design, etc.) as well as the characteristics of the insured population (e.g., demographics and risk profile).

Demographic factor is a summary measure that reflects family size, gender, and age. Plan design captures the generosity of benefits, including the level of copayments required of enrollees. The exact formulae used to calculate these factors were not disclosed to me. It is worth noting, however, that my source uses these factors to normalize and then compare premiums across plans and firms, and they are an industry leader in healthplan selection and design. The decline in plan design during the study period is also noteworthy, as it is consistent with reports that employers have reduced benefits in an effort to contain cost growth (so-called "benefit buybacks").

Four plan types are represented in the data. Ordered by the restrictiveness of the provider network for each plan, these are: Indemnity (all providers covered), PPO (preferred providers fully covered, non-preferred providers covered in part), POS ("point of service" plan: care is "managed" as in an HMO, and if approval for a service is obtained preferred providers are covered in full and non-preferred providers in part), and HMO (care is managed and preferred providers are fully covered). Approximately 90 percent of the plans in the LEHID FI-Compustat sample are HMOs.

\footnotetext{
${ }^{19}$ Premiums are reported in nominal dollars. All specifications use $\ln$ (premium) as the dependent variable and include year fixed effects, so nationwide deflators will not affect the coefficients of interest.
} 
As discussed above, profit is lagged two years to reflect the timeline for plan selection. Thus the 2001 recession is apparent in the summary statistics for 2003 . The recession had varying impacts across firms and sectors, as evidenced by the large increase in the standard deviation in 2003. This is precisely the type of variation that identifies the effect of interest.

The LEHID FI-Compustat sample includes an average of 144 employers and 102 markets per year. The decline in observations during the last two years reflects both the trend away from FI plans, and a general decline in the number of employers in the LEHID sample. ${ }^{20}$ These trends are apparent in Appendix Table 1, which gives the number of employers included in LEHID in every year, together with the share with at least 1 FI plan and at least 1 SI plan.

\section{Do Profitable Firms Pay More For Health Insurance?}

\subsection{Main Analysis}

My empirical strategy relies on the assumption that employers are willing to pay more for health insurance when profits are high (why is the subject of Sections 5 and 6). If true, insurance carriers may exploit this circumstance by adjusting premiums accordingly. The key regression relates plan premiums to lagged employer profits. Recall a plan is an employer-geographic market- insurance carrier-plan type combination, denoted by the subscript emcj. The first specification can be expressed as follows:

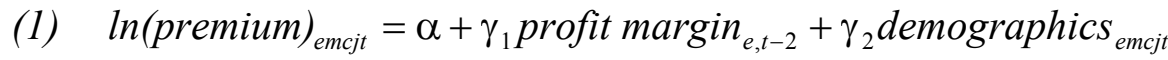

$$
\begin{aligned}
& +\xi_{e}+v_{m}+\psi_{c}+\eta_{j}+\delta_{t}+\omega_{j t}+\zeta_{e m} \\
& {\left[+\rho_{e m c j}\right]\left[+X_{m t} \beta\right]\left[+\phi_{m t}\right]+\varepsilon_{e m c j t}}
\end{aligned}
$$

\footnotetext{
${ }^{20}$ The decline is heightened by the sample restriction that drops all observations in market-years with fewer than 20 employers offering at least 1 fully-insured plan. In section 6, I confirm the results are similar when this restriction is lifted.
} 
Equation (1) includes fixed effects for each employer $e$, market $m$, carrier $c$, plan type $j$, and year $t$. Employer fixed effects help to capture unobserved, time-invariant differences in the composition of the population covered, benefit design, and usage patterns for a given employer, all of which affect plan premiums. Market fixed effects capture differences in medical costs (e.g., due to local wages) and practice. There is a literature that documents substantial differences in medical practice and utilization (though, interestingly, not in outcomes) across geographic markets (e.g., Wennberg, Fisher, and Skinner (2002)). Plan type fixed effects capture average price differences for these broad product groups, and carrier fixed effects capture average price differences across carriers due to time-invariant characteristics such as reputation. Finally, year fixed effects absorb annual growth in premiums nationwide.

There are nine "second-order interactions" that could theoretically be included in this specification, however it is neither computationally feasible nor economically sensible to include them all in the baseline model. ${ }^{21}$ I rely on institutional knowledge to select two to include in all specifications: plan type-year effects $\left(\omega_{j t}\right)$ and employer-market effects $\left(\boldsymbol{\zeta}_{e m}\right)$. (The remaining 7 will eventually be included in models discussed below.) The plan typeyear effects absorb different premium growth patterns across plan types, such as the wellknown increase in HMO premiums associated with a loosening of HMO restrictions during this era of "managed care backlash." The employer-market interactions capture premium differentials associated with differences in the composition of employee populations and/or unobserved plan generosity across markets, e.g. headquarters vs. retail locations. These interactions will also capture premium differentials associated with employers who are expanding versus contracting the number of markets in which they operate. To the extent expanding employers are both more profitable and more generous with insurance benefits (in dimensions not captured by the covariates already in the model), the coefficient on profits could be upward-biased in the absence of these interactions.

\footnotetext{
${ }^{21}$ Note employer-year fixed effects cannot be included, as this is the level of variation of the explanatory variable of interest.
} 
Adding additional interaction terms to the model (whether second-order or greater) reduces the possibility of omitted variables bias but also eliminates potentially exogenous variation that can be used to identify $\gamma_{1}$. In recognition of this tradeoff, I present results for specifications with and without the bracketed terms in equation 1. I begin by introducing fixed effects for each employer-market-plan type-carrier combination $\left(\boldsymbol{\rho}_{e m c j}\right)$. Once these "plan fixed effects" are included, $\gamma_{1}$ is identified by within-plan changes in premiums and changes in the profits of affiliated employers (due to the inclusion of employer fixed effects).

The key advantage of including plan fixed effects is the elimination of cross-sectional variation as a source of identification for $\gamma_{1}$. For example, if firms experiencing positive profit shocks tend to choose generous benefit packages (within a given plan type and carrier), in the absence of plan fixed effects $\gamma_{1}$ will reflect these omitted factors. However, some of this cross-sectional variation may be desirable because competing plans act as a constraint on the pricing of incumbent providers. Faced with an excessive price increase, some employers may switch plans to obtain better pricing. Plan fixed effects eliminate any variation in price due to such switching. Thus, the baseline model reveals whether employers facing profit shocks end up paying higher premiums on average (regardless of switching behavior), while the models with plan fixed effects reveal whether these employers pay more for the same plans. Note the plan fixed effects also subsume 5 of the remaining 7 second-order interaction terms. $^{22}$ The final two, market-year fixed effects and carrier-year fixed effects, are addressed below.

I begin by adding market-year measures of economic conditions (the unemployment rate) and costs (the per-enrollee average Medicare expenditure, known as the AAPCC) to capture changes in economic conditions and healthcare trends that may be correlated with both employer profits and premiums. These are denoted by $X_{m t}$. If the coefficients of interest are sensitive to the inclusion of these covariates, market-year fixed effects (denoted $\left.\phi_{m t}\right)$ are advisable. Once included, $\gamma_{1}$ is identified by differences in within-plan premium

\footnotetext{
${ }^{22}$ The five interactions are: employer-carrier, employer-plantype, market-carrier, market-plantype, and carrierplantype. Plan fixed effects also subsume the employer-market fixed effects included in all specifications, so technically they capture 6 of the 9 possible second-order interaction terms.
} 
growth for plans operating in the same market. To clarify this source of identification, consider as a hypothetical example the Chicago-based healthplans offered by Boeing and United Airlines in 2003. In the wake of September 11, 2001, United filed for bankruptcy while Boeing's fortunes soared. Controlling for the average premium growth in Chicago, as well as the average premium growth for specific plan types nationwide, I expect premium increases to be higher for Boeing if $\gamma_{1}$ is positive. ${ }^{23}$ Of course, a cost of including marketyear interactions is that variations in average firm profits in a given market cannot help to identify the coefficient of interest. For example, many California-based firms benefited from the technology boom in 1999-2000. The extent to which insurers were able to capture these rents will not be reflected in the estimates obtained from models with market-year fixed effects. (On the other hand, neither would the effect of (hypothetically) faster-than-normal cost growth in California be mislabeled as "rent extraction." Of course, the impact of the economic controls on the profit coefficient will reveal the likelihood of such a bias.) For the sake of completeness, I also confirm the sensitivity of the results to the inclusion of carrieryear interaction terms, although these are unlikely to generate bias in the coefficient of interest. $^{24}$

Because premium rates for the same plan (i.e. emcj combination) are likely to be serially correlated over time, I perform a formal test as described in Wooldridge (2002). ${ }^{25}$ I reject the null hypothesis of no serial correlation with a p-value smaller than .001 . Given the unbalanced nature of the panel, I cannot implement a fully robust estimator (i.e. FGLS that allows for any heteroskedasticity and serial correlation in the error terms), however I can and do correct for AR(1) correlation in the errors using an FGLS estimator designed for this circumstance by Baltagi and $\mathrm{Wu}(1999) .{ }^{26}$

\footnotetext{
${ }^{23}$ Note this final model effectively includes all nine second-order interaction terms.

${ }^{24}$ Carrier-year interactions will be significant predictors of premiums if carrier-specific financial conditions impact premium increases. However, excluding these interactions will only bias the coefficient of interest if employers with high or low profit shocks are disproportionately represented in the customer base of insurers experiencing systematically good or bad years. Particularly after market-year interaction terms are included in the specification, such a scenario is difficult to envision.

${ }^{25}$ This test consists of running the first-differenced version of equations (1) or (2) and regressing the resulting residuals on their one-period lag. A coefficient significantly different from -0.5 implies serial correlation.

${ }^{26}$ The Baltagi-Wu estimator is implemented by the stata command xtregar. For models without plan fixed effects, the analogous command is xtpcse. An alternative (though inefficient) approach is to use OLS and
} 
Table 2 presents results for the 4 specifications represented by equation (1). The estimates of $\gamma_{1}$ are all positive, similar in magnitude, and statistically significant. The point estimate increases upon inclusion of plan fixed effects, and is unaffected by the market-year covariates. This suggests local economic conditions and/or changes in healthcare utilization are unlikely to be driving the results. Controlling for differences in premium growth across markets (column 7) reduces the magnitude of $\hat{\gamma}_{1}$ a bit, but this difference is not statistically significant. Though not reported in the table, adding carrier-year interactions has virtually no impact on the coefficient estimates. The results imply an employer with a 10-percentage point increase in profits can expect to pay approximately 0.3 percent more in health insurance premiums, ceteris paribus.

Next, I consider the possibility of bias due to changes in unobserved plan characteristics, such as provider networks, prescription drug formularies, and copayments. An alternative explanation for the positive estimate of $\gamma_{1}$ is that firms with positive profit shocks respond by increasing benefits for workers, and more benefits come with a higher price tag. As a first test of this hypothesis, I add plan design to each specification. The results are reported in columns 2, 4, 6, and 8 of Table 2, alongside the corresponding baseline specifications. The coefficient on plan design is always positive and highly significant, suggesting it does capture the generosity of benefits. However, the estimates of $\gamma_{1}$ remain significant, and actually increase a bit (counter to the hypothesized direction of any omitted variables bias). To the extent that other omitted, time-varying plan characteristics are correlated with this composite measure, this test provides some reassurance that these omitted factors are not generating the positive estimates of $\gamma_{1}$.

As a second test of this alternative explanation, I consider how the estimate of $\gamma_{1}$ varies by the market structure of the local insurance industry. If $\gamma_{1}$ reflects rent extraction by insurance carriers, it should be larger where competition is less fierce. If instead it reflects the predilection of profitable employers to provide more generous benefits, it should be

cluster the standard errors by plan. The point estimates are similar, but the standard errors tend to be larger (as expected). 
insensitive to the market structure of the insurance industry: there is no obvious reason why multisite firms with high profits would increase benefits most in the sites served by a concentrated insurance sector. ${ }^{27}$ I estimate models based on the following equation:

$$
\begin{aligned}
\ln (\text { premium })_{\text {emcjt }}= & \alpha+\sum_{N C=1}^{5} \gamma_{1, N C} 1(N C)_{m} * \text { profit margin } \text { met }-2+\sum_{N C=1}^{4} \lambda_{N C} 1(N C)_{m t} \\
& +\gamma_{2} \text { demographics }_{e m c j t}+\gamma_{3} \text { plan design } \text { emcjt }+\xi_{e}+v_{m}+\psi_{c}+\eta_{j}+\delta_{t} \\
& +\omega_{j t}+\varsigma_{e m}\left[+\rho_{e m c j}\right]\left[+X_{m t} \beta\right]\left[+\phi_{m t}\right]+\varepsilon_{e m c j t}
\end{aligned}
$$

where NC stands for "number of carriers." I use 5 ranges for number of carriers: 1-4, 5-6, 78, 9-10, and 11+. (As indicated in Figure 5, these categories capture the distribution of number of carriers fairly well; unfortunately there is insufficient data to subdivide the 1-4 category further.) $1(\mathrm{NC})_{\mathrm{mt}}$ is an indicator variable that takes a value of 1 if the observation is from a market-year with NC carriers. Thus, $\gamma_{1,3}$ is estimated from observations in marketyears with 7-8 carriers. Although an imperfect proxy for market competitiveness, the number of carriers is the most accurate measure of market structure available to me given the non-random nature of the sample. (In the Online Appendix, I confirm the results are robust to replacing these categories with quintiles for HHI.) Equation (2) also includes the number of carrier indicators to control for any market-wide effects of entry and exit on premiums.

Table 3 illustrates that the magnitude of $\hat{\gamma}_{1, N C}$ declines as the number of carriers increases. T-tests reject the null hypothesis $\hat{\gamma}_{1,1}=\hat{\gamma}_{1,5}$ in favor of $\hat{\gamma}_{1,1}>\hat{\gamma}_{1,5}$ in all specifications with p-values of .07 or less. The relationship between profits and premiums in the most competitive markets is not significant in any of the specifications. The point estimates are affected little by the addition of market-year covariates, indicating that differences in local economic and healthcare utilization trends are unlikely to be generating the observed sensitivity of premiums to profits in markets with few carriers. The coefficient on markets with 5-6 carriers declines in the specification with market-year fixed effects, but

\footnotetext{
${ }^{27}$ Similarly, profitable firms could respond to profit shocks by hiring more experienced employees who are older and costlier to insure.
} 
otherwise the results remain similar even in this stringent specification, as well as in the unreported specification that adds carrier-year fixed effects. ${ }^{28}$

The estimates indicate that profitable firms pay more for their health insurance, ceteris paribus. This effect is only significant in markets with 10 or fewer major carriers, and is most pronounced in markets with 6 or fewer carriers. In such markets, a profit increase of 10 percentage points (roughly the standard deviation of profits during the 2001 recession) is associated with an increase in health insurance premiums of 1.2 percent. $^{29}$

The evidence that suppliers enjoy significant market power even when up to 10 competitors are present is consistent with related research in industrial organization. Although a much smaller number of players is needed to achieve perfect competition in a homogenous product market (Bresnahan and Reiss 1991), the number in a differentiated product market can be a good deal larger. Dranove, Gron and Mazzeo (2001) report evidence that the sixth HMO in an MSA earns supracompetitive profits, on average. (Estimates for entrants beyond the sixth are not reported.) Once they categorize the HMOs by whether they have national networks, they find steeper declines in profits with additional entrants of the same type, although they do not report the maximal number of each type associated with positive profits. Given the many dimensions along which insurance carriers are differentiated, the result that 10 or more are needed, on average, to inhibit customerspecific rent extraction is in line with theoretical and empirical predictions.

\subsection{Alternative Explanations}

In this section, I consider alternative explanations for the key findings. The first alternative explanation is that profitable firms increase the generosity of their plans more in more concentrated insurance markets. To examine this possibility, I re-estimated the models above using plan design as the dependent variable. Although changes in plan design itself will not

\footnotetext{
${ }^{28}$ The coefficient estimates for the number of carrier indicators are available upon request. These are identified by changes in the number of carriers within a given market over time due to entry, exit, and measurement error. The results are robust to the exclusion of the number of carriers indicators.

${ }^{29}$ I obtain this estimate using the average of the relevant coefficients in the specification with plan fixed effects and market-year covariates (column 3, Table 3): $\exp \left(((.145+.092) / 2)^{*} .1\right)=1.012$.
} 
impact the estimates I report because it is included as a control in the key specifications, to the extent plan design is correlated with unobservable generosity this analysis will shed light on the feasibility of this alternative explanation. The results, reported in the Online Appendix as Tables OA1 and OA2, show that employers experiencing positive profit shocks do not tend to increase plan quality nationwide (rather, they decrease it), nor do they increase quality relatively more in more concentrated insurance markets.

A second, related concern is that insurer markups for plan quality may be higher in more concentrated markets. A higher markup for quality in concentrated markets could yield a similar pattern of results even if the increase in quality is the same across all markets. Moreover, to the extent that concentrated insurance markets coincide with concentrated healthcare provider markets, such a pattern of markups could reflect the exercise of market power by the latter (or perhaps some combination of the two). Although the preceding analysis suggests profitable firms do not increase plan quality, to consider this alternative explanation directly I re-estimate the specifications represented by equation (2) with the addition of interactions between number of carrier categories and plan design. The estimates are presented in Table 4. The coefficients and standard errors on the interactions between market structure and lagged profits are virtually unchanged. In addition, there is little evidence that the markup for plan quality is higher in more concentrated markets. The point estimates are only larger for more concentrated markets in one of the four specifications (the model without plan fixed effects), and even in this specification the difference between the coefficient on plan design for the most and least concentrated markets is not statistically distinguishable from zero.

The preceding analysis raises the question: are there other factors correlated with insurer concentration that could be producing the observed pattern of findings? Table OA3 in the Online Appendix presents descriptive statistics for the market-years in each category. The table shows that the most concentrated markets have smaller populations, lower income per capita, and are less urban than the least concentrated markets. However, it is important to recognize that the analysis of rent extraction does not examine the relationship between market structure and premium levels, which could certainly be affected by these other 
characteristics. Rather, the study investigates how individual insurance contracts are revised to reflect changes in individual customer characteristics. It is difficult to conceive of a mechanism whereby differences in the underlying attractiveness of a market - or in any other market-specific characteristics - could generate the observed behavior. For example, one unobserved market characteristic is provider concentration. Even if provider concentration is correlated with insurer concentration, the former cannot price-discriminate across specific employers when insurers serve as intermediaries. Finally, the impact of any differences across market-years in demographics or provider concentration are controlled for in specifications with market-year fixed effects.

\subsection{Robustness and Extensions}

I performed several robustness checks and additional analyses to corroborate and extend the key results. First, I used the first-differences (FD) estimator in place of the FGLS estimator for models that include plan fixed effects. Although the FD estimator is inefficient due to the serial correlation in the error terms, it should be unbiased. ${ }^{30}$ I reorganized the data into firstdifferences (where the unit of observation is a plan) and estimated the following specification:

(3) $\Delta \ln (\text { premium })_{\text {emcj(t,t-1)}}=\alpha+\vartheta_{1} \Delta$ profit $\operatorname{margin}_{e(t-2, t-3)}+$

$$
\begin{aligned}
& \vartheta_{3} \Delta \text { demographics } \text { emcj }(t, t-1)_{1}+\vartheta_{4} \Delta \text { plan design } \text { emcj }(t, t-1)+ \\
& \delta_{t}+\omega_{j t}+\left[+\phi_{m t}\right]+\Delta \varepsilon_{\text {emcitit } t-1)} .
\end{aligned}
$$

This specification corresponds to specification (1) after plan design and plan fixed effects are included (i.e., Table 2, columns 4 and 8). I also estimated analogous models with the number of carrier dummies*profit margin interactions. The results, presented in Table 5, are fairly similar to the FGLS results. Although the coefficient estimates are smaller, the key coefficients remain statistically significant at $\mathrm{p}<.01{ }^{31}$

\footnotetext{
${ }^{30}$ Two additional advantage of the FGLS estimator are: (1) it enables comparisons of estimates with and without plan fixed effects; (2) it retains more data points given the unbalanced nature of the panel.

${ }^{31}$ I also used the first-differenced data to see whether the rent extraction parameter differs for employers experiencing positive vs. negative profit shocks. I added the term

$\vartheta_{2} \Delta_{\text {profit } \operatorname{margin}_{e(t-2, t-3)}} \cdot 1\left(\Delta\right.$ profit margin $\left._{e(t-2, t-3)}>0\right)$ to equation (3), where $1\left(\operatorname{pprofit}_{\operatorname{margin}_{e(t-2, t-3)}}>0\right.$ is an
} 
Next, I performed a falsification exercise using data on self-insured (SI) plans. ${ }^{32}$ Because reported "premiums" for self-insured include expected fees charged by the carriers who administer these plans, evidence of rent extraction may be apparent in the data. However, the relationship should be weaker than that observed in the fully-insured market, as error in the dependent variable is substantial (because projections are imperfect measures of realized costs), there are more competitors in the self-insured market, and fee structures for administrative services are far more transparent than pricing for fully-insured plans. ${ }^{33}$

Using the sample of self-insured plans in the same market-years included in the analysis of fully-insured plans, I estimate models (1) and (2) from section 4.1 (i.e., the levels specifications). The dependent variable is the log of the employer's estimate of outlays for each plan-year ( $\ln ($ ("premium”). The indicators for number of carriers still refer to FI carriers. Using the FI market structure is the likeliest way to reveal whether the main results are spurious. In addition, the self-insured market is less concentrated, precluding identification of $\gamma_{1, N C}$ in markets with small numbers of SI carriers. The results show a negative relationship between lagged profits and estimated outlays. Decomposing the relationship by market structure reveals no steady pattern. To the extent the projected costs of SI plans are an appropriate counterfactual for FI plans, these findings suggest the main results are not spurious.

Most employers in the sample offer one or more self-insured plans alongside their fully-insured choice(s). The substitutability of self and full insurance raises two interesting extensions: First, are firms likelier to self-insure in the wake of profit shocks due to the higher premiums they face for full insurance? Second, do they end up paying more on average (across all plans) following profit shocks, and is this increase smaller in markets with more FI carriers? To answer these questions, I use data on all plans offered by employers in

indicator for a positive profit shock. The results were inconclusive, i.e. I am unable to reject the null of symmetric rent extraction parameters.

${ }^{32}$ I thank Mark Pauly for this suggestion.

${ }^{33}$ More transparent pricing should limit the ability of insurers to price-discriminate. Although contract structure varies, it typically specifies fees per enrollee and/or per claim.) 
the LEHID-FI-Compustat sample, regardless of whether an FI plan is offered in a particular year. I aggregate the data to the employer-market-year level and estimate models using both percent self-insured and ln(average "premium") as dependent variables, where "premium" reflects both full-insurance premiums and expected outlays for self-insured enrollees.

A detailed discussion of the data, together with descriptive statistics and tables of results are given in Appendix A. I find no evidence that employers are more likely to rely on self-insured plans in the wake of profit shocks. In concentrated insurance markets, average "premiums" rise with profit shocks, even when incorporating possible substitution toward self-insured plans.

There are several possible reasons profitable employers are not more likely to switch toward self-insurance in spite of the price increases they face relative to less profitable employers. The timeframe for making a decision to switch to self-insurance may be lengthy. The right vendors must be identified and contracts written. Self-insured firms must maintain adequate financial reserves to pay claims as they are realized, and they must bear the risk of unpredictable medical expenses. Perhaps most important: profitable firms may be reluctant to make any major changes to their plan portfolios for reasons I describe in section 5 .

Another important robustness check concerns the implicit assumption that premiums for each plan-year are set independently. Multisite firms negotiating with multimarket insurers may agree to premiums for many sites at once. To the extent this occurs in my sample, the estimates I obtain in Table 3 are conservative because price changes for these firms will not vary with the concentration of local insurance markets. Unfortunately, there is no direct indicator of multisite contracts in the data. ${ }^{34} \mathrm{I}$ therefore pursue a conservative approach to identifying jointly-negotiated contracts. I identify employer-carrier-plantype combinations that are the same across multiple markets, and assume any that share the exact same value for plan design (a continuous measure) are jointly-negotiated. Then, I include

\footnotetext{
${ }^{34}$ Regrettably, the premium variable cannot be used to infer which plans are part of such a contract. I observe the average premium per plan-year. Even if Company X's Aetna HMO charges the same premium, by family size, across all markets, the average premium will take on different values across these markets due to differences in average family size at each site.
} 
only one observation for this set of plans in the estimation sample. ${ }^{35}$ As expected, the results (reported in the Online Appendix as Tables OA4 and OA5) are generally stronger, although the sample size falls by nearly one-half and the standard errors increase accordingly.

The Online Appendix also includes tables of results from several additional analyses. I evaluate the impacts of each of the following changes in turn: (1) weighting each observation by the number of enrollees; (2) dropping data from 2004 and 2005, the years in which the number of markets in the sample declines substantially due to the restriction that 20+ employers be sampled in each market-year; (3) expanding the estimation sample to include all market-years (not just those with 20+ employers); (4) restricting the sample to HMOs only, which account for more than 90 percent of fully-insured plans; (5) using alternative profit measures; (6) using quintiles of the HHI as a measure of market concentration (rather than the number of carriers); (7) using different approaches to counting the number of carriers. All key patterns remain statistically significant, and are often stronger, when any of these changes is implemented.

\section{Interpreting the Results: Combining Practitioner Intuition and Bargaining Theory}

\subsection{Practitioner Intuition}

The results of the prior section imply that firms are willing to pay more for health insurance when times are good, and in concentrated insurance markets carriers successfully extract some (or all) of this increased willingness-to-pay. This begs the question of why firms fail to minimize costs regardless of profit level. Although cost minimization is a key assumption of neoclassical economics, the business press is replete with anecdotal evidence of profligate spending during booms and inefficient cost-cutting during busts. These inefficiencies have

\footnotetext{
${ }^{35}$ For example, suppose Company X offers a BCBS PPO in 30 markets. If plan design-a continuous measure that captures the generosity of copays and coverage - is the same across these markets, I include only 1 of these plans in the estimation sample. If it is the same across 10 of the markets, then I include 1 of these 10 plans and all of the remaining 20 plans in the sample.
} 
also been corroborated in research by Borenstein and Farrell (2007). ${ }^{36}$ Borenstein and Farrell find stock market valuations of gold mining firms are concave in the price of gold. Given the perfectly competitive output market, this result is consistent with a decrease in cost efficiency when profits are high.

A potential source of cost inefficiencies in "fat firms" is rent-sharing with workers, or to be more precise, rent-sharing that is not part of an optimal labor contract. ${ }^{37}$ Borenstein and Farrell do not find evidence of rent-sharing in the mining sector, but it has been documented in a number of industries and countries (e.g., Dickens and Katz 1987, Katz and Summers 1989, and Blanchflower et al. 1996). Although empirical evidence of rent-sharing focuses on wages, the relationship with fringe benefits such as health insurance may be similar, as there is some evidence that benefits and wages are interchangeable (e.g., Gruber 1994 and Pauly 1998). When presented with my findings, industry experts suggested precisely such an explanation. $^{38}$

The argument proffered by the experts is linked to the high switching costs employees must incur when changing healthplans. These costs include: learning about changes in benefit coverage and design and potentially adjusting healthcare consumption as a result; identifying providers that belong to the new plan's network; if former providers are not part of the network, scheduling and undergoing new patient visits (which may lead to a disruption in care and associated medical consequences), transferring medical records and prescriptions, and, for plans with "gatekeepers" (such as HMOs or POS plans) navigating through a gatekeeper in order to see specialists; figuring out the claims reimbursement system. For employers to obtain the best pricing on plans, they must be willing to change carriers. However, a plan switch is a "tough sell" in good times, to paraphrase an executive

\footnotetext{
${ }^{36}$ Writing in BusinessWeek in March 2008, former General Motors head Jack Welch and co-columnist Suzy Welch advise firms to "trim the fat" to cope with the economic slump. "Years of sustained growth practically guarantee some padding," they note, citing as examples excessive overhead, non-essential consulting projects, and "the quality of company gatherings." (3/3/2008, p. 88).

${ }^{37}$ Rent-sharing may of course be optimal, particularly if workers and firms are risk-averse (Blanchflower 1996) or if specific investments are required for both parties.

${ }^{38}$ This explanation was proposed by an executive from my data source, and subsequently corroborated in interviews with a large insurance broker/former insurance executive (phone interviews, 10/9/2007 and 10/10/2007), and a CFO at a leading health insurer (phone interview, 10/25/2007). All sources requested anonymity.
} 
from my data source. Workers are willing to tolerate such actions (along with, say, the holiday party in the office conference room), but only when viewed as necessary. Thus profitable firms may share rents with workers by retaining existing plans.

While this hypothesis may explain why insurers can extract higher rents from more profitable firms on average, it does not explain why this extraction is more successful in markets where fewer insurers compete. To obtain some intuition for this result, I formulate a simple bargaining model that captures the key elements of this setting.

\subsection{A Bargaining Model}

Assume each employer $e$ purchases insurance from only one insurer $i$, both parties have full information, and the transaction price is determined through Nash bargaining. (A more realistic model would accommodate the possibility of multiple contracts, as well as asymmetric information on both sides, but this is beyond the scope of this paper.) Denote the employer's value of purchasing insurance from $i$ (that is, the employer's willingness-topay) by $v_{i e} \cdot v_{i e}$ is a function of employee demographics and risk profiles $X_{e}$, employer profits $\pi_{e}$, insurer characteristics $X_{i}$, plan design $q$, and an additive i.i.d. error term $u_{i e}$ that represents idiosyncratic variation in the employer's valuation of its healthplan in a given year (e.g. due to the preferences of a new benefits manager, or bad publicity surrounding a particular insurer).

(5.21) $v_{i e}=\left[g\left(X_{e}, \pi_{e}, X_{i}, q\right)+u_{i e}\right]$

The employer's value of the next-best option $\left(v_{-i e}\right)$ is similarly constructed, however I replace $X_{-i}$ with $\mathrm{N}$, the number of insurers. $\mathrm{N}$ is arguably a reasonable proxy for the attractiveness of the next-best option, as more choices should increase the likelihood of a good match. The cost of insuring $e$ is assumed constant across insurers (this assumption is not necessary for the results that follow and is imposed in the interest of parsimony). 
The surplus from trade between $e$ and $i$, denoted $S_{i e}$, can be written

$$
S_{i e}=\left[v_{i e}-v_{-i e}\right]=\left[g\left(X_{e}, \pi_{e}, X_{i}, q\right)+u_{i e}\right]-\left[h\left(X_{e}, \pi_{e}, N, q\right)+u_{-i e}\right]
$$

Under the assumption of perfect information, trade will take place when surplus is positive. The division of surplus is determined by $0 \leq \alpha(\mathrm{N}) \leq 1$; this parameter reflects the insurer's bargaining power. Denoting the amount of surplus going to the insurer by $P$ (for price or premium), we have

$$
P_{i e}=\alpha(N) * S_{i e}\left(X_{e}, \pi_{e}, X_{i}, q, N, u_{i e}, u_{-i e}\right) .
$$

In words, premium is determined by relative bargaining power, employee demographics and risk profiles, employer profits, the employer's choice of plan quality, and the extent of competition in the marketplace. ${ }^{39}$ Most of the regression specifications focus on changes in premiums for the same ie pair. Thus, identification in these models derives from changes in demographics, profits, and plan quality, all interacted with bargaining power (which itself may vary if there is entry and exit). ${ }^{40}$

I use this model to derive the implications of a change to employer profits. There are two readily-available outcomes to consider: price and the probability of trade. It is easy to see that premiums for observed contracts only increase in profits, i.e. $\partial P_{i e} / \partial \pi_{e}>0$ (the empirical result of section 3), if $\partial g / \partial \pi_{e}>\partial h / \partial \pi_{e}$. In light of the results presented thus far, this condition implies profits increase the employer's relative value of remaining with an incumbent. This could be evidence of inefficient cost-minimization practices (i.e. inertia) associated with profits (a la Borenstein and Farrell's "fat firms"), or of a profit-induced shock to switching costs (as suggested by the industry experts). In either case, these relative

\footnotetext{
${ }^{39}$ It would be more straightforward to include terms for insurer characteristics in the model, but using the number of competitors proves far more convenient when deriving the results.

${ }^{40}$ Although the empirical models do not explicitly include interactions between demographics and market structure, the results are robust to these terms.
} 
changes in willingness-to-pay will not result in higher premiums unless insurers have positive bargaining power, i.e. $\alpha>0$.

Next, consider the effect of a profit shock on the probability that an employer and an insurer who traded in a prior period (i.e. the incumbent insurer-employer combination, for which $S_{i e}$ was positive) part ways. Denoting the cumulative probability distribution of $\left(u_{e i}-u_{-i e}\right)$ by $F$ (assumed to be twice differentiable), we have

$\operatorname{Prob}\left(S_{i e}<0\right)=\operatorname{Prob}\left(u_{i e}-u_{-i e}<\left(h\left(X_{e}, \pi_{e}, q, N\right)-g\left(X_{e}, \pi_{e}, q, X_{i}\right)\right)\right)=F\left(h\left(X_{e}, \pi_{e}, q, N\right)-g\left(X_{e}, \pi_{e}, q, X_{i}\right)\right)$

and (5.25)

$\partial F\left(h\left(X_{e}, \pi_{e}, q, N\right)-g\left(X_{e}, \pi_{e}, q, X_{i}\right)\right) / \partial \pi_{e}=f\left(h\left(X_{e}, \pi_{e}, q, N\right)-g\left(X_{e}, \pi_{e}, q, X_{i}\right)\right) *\left(\partial h / \partial \pi_{e}-\partial g / \partial \pi_{e}\right)$.

Given a probability density function is weakly positive everywhere, and the empirical results indicate the second term is negative, we have the first additional empirical prediction: the probability that an employer and an insurer part ways should decline in profits.

Next, consider how these predictions vary by the number of insurers in the market, beginning with price :

$$
\partial^{2} P / \partial \pi_{e} \partial N=\partial \alpha / \partial N^{*}\left(\partial g / \partial \pi_{e}-\partial h / \partial \pi_{e}\right)-\alpha^{*}\left(\partial^{2} h / \partial \pi_{e} \partial N\right)
$$

From the empirical results, we know $\partial^{2} P / \partial \pi_{e} \partial N<0$ and $\left(\partial g / \partial \pi_{e}-\partial h / \partial \pi_{e}\right)>0$. Thus, either insurer bargaining power declines in the number of insurers $(\partial \alpha / \partial N<0)$, the effect of profit shocks on the value of the employer's outside option increases in the number of 
insurers $\left(\partial^{2} h / \partial \pi_{e} \partial N>0\right)$, or both. ${ }^{41}$ If $\partial^{2} h / \partial \pi_{e} \partial N$ can be shown to be negative, then we can definitively conclude that insurer bargaining power declines in the number of insurers.

Unfortunately, I do not directly observe each employer's best outside option.

However, I obtain some additional insight by examining how the number of insurers affects the predictions vis-à-vis match dissolution:

$$
\begin{aligned}
\frac{\partial^{2} F\left(h\left(X_{e}, \pi_{e}, q, N\right)-g\left(X_{e}, X_{i}\right)\right)}{\partial \pi_{e} \partial N} & =f\left(h\left(X_{e}, \pi_{e}, q, N\right)-g\left(X_{e}, \pi_{e}, q, X_{i}\right)\right) *\left(\frac{\partial^{2} h}{\partial \pi_{e} \partial N}\right) \\
& +f^{\prime}\left(h\left(X_{e}, \pi_{e}, q, N\right)-g\left(X_{e}, \pi_{e}, q, X_{i}\right)\right) *\left(\frac{\partial h}{\partial N}\right) *\left[\frac{\partial h}{\partial \pi_{e}}-\frac{\partial g}{\partial \pi_{e}}\right]
\end{aligned}
$$

This cross-partial can be signed empirically by seeing how the rate of match dissolution with respect to profits varies with $\mathrm{N}$. This is the second empirical test I perform in the next section. Although the second of the two terms on the right-hand-side is of indeterminate sign because $\mathrm{f}^{\prime}()$ cannot be signed, an empirical finding that $\partial^{2} F() / \partial \pi_{e} \partial N<0$ is consistent with $\partial^{2} h / \partial \pi_{e} \partial N<0$. That is, if profitable firms are less likely to switch carriers in more competitive insurance markets, this suggests that the effect of profits on the outside option decreases in N. Returning to (5.26), this strengthens the case for $\partial \alpha / \partial N<0$.

To summarize, the model provides the following insights: (1) the rent-extraction result of section 3 appears to be due to a combination of insurer bargaining power (i.e. $\alpha>0$ ) and employer inertia or switching costs; (2) employers with profit shocks should be less likely to switch carriers; (3) the fact that rent extraction is weaker in markets with more insurers is consistent with two explanations: lower insurer bargaining power in such markets, and/or less of an increase in profit-induced inertia or switching costs in these markets; (4) if employers with profit shocks are less likely to switch in markets with large numbers of carriers, the second explanation is less likely to be driving the results.

\footnotetext{
${ }^{41}$ Technically, of course, other combinations are possible, but not intuitive.
} 


\section{The Relationship between Plan Switching and Employer Profits}

This section tests the predictions regarding the propensity of firms to switch healthplans. I begin by investigating whether switching is less likely when firms are profitable, controlling for other factors that may be associated with the propensity to switch. To analyze switching behavior, I create a dataset of employer-market-year observations and estimate linear probability models of the following form:

$$
\text { switch }_{e m(t, t-1)}=\alpha+\text { pprofit margin } \text { mat }_{t}+\tau_{t}\left[+\phi_{m t}\right]\left[+\xi_{e}\right]\left[+\varsigma_{e m}\right]+\varepsilon_{e m t} .
$$

I define two versions of switch: carrierswitch and planswitch. carrierswitch takes a value of 1 if there is an addition or deletion of insurance carriers by an employer in a given market between $t-1$ and $t$. Planswitch takes a value of 1 if there is an addition or deletion of carrierplantypes. Planswitch will overstate switching, e.g., if a firm switches from a UnitedHealthcare HMO to a UnitedHealthcare POS, it will be coded as having made a switch when no material switch has occurred. carrierswitch will understate switching, e.g., if a firm offers an Aetna HMO, Aetna PPO, and UnitedHealthcare PPO, and eliminates the Aetna PPO, it will not be coded as having made a switch. For this reason, I present estimates using both measures. $^{42}$

The baseline model captures the association between lagged profits and the propensity to switch, controlling for national trends. The next specification adds market-year interactions to control for general upheaval in a market-year due, for example, to mergers or exits of insurance carriers. Absent these interactions, the estimate of $\varphi$ will reflect such activity if it is correlated with market-level changes in lagged profits of employers. Employer fixed effects are added next; these control for any employer-specific tendencies to switch, which may also be correlated with profit levels and hence bias the estimate of $\varphi$. For

\footnotetext{
${ }^{42}$ To reduce measurement error, the switch variables are defined only when data from two adjacent years is available. Unfortunately, error due to mergers, acquisitions, and divestments of insurers and employers cannot be purged from these variables. Market-year fixed effects will, however, control for such changes in the local insurance market.
} 
example, employers in sectors with high labor turnover may switch healthplans more often because their employees are less likely to have a continuous relationship with a healthplan and/or its associated providers. If such employers also tend to report lower profits, the estimate of $\varphi$ could be biased downward in the absence of employer fixed effects. Note also that after employer fixed effects are included, $\varphi$ is identified by within-employer changes in profits. Last, I add employer-market fixed effects, which allow for different baseline switching levels across employer-markets. For example, employees of a large retail chain may differ across locations, with headquarters employees expecting steady benefits and retail clerks in all other markets willing to tolerate switches more readily.

I estimate the switching specifications on the entire sample of employer-market-year observations with Compustat data, and on the subset of observations with at least one fullyinsured plan and located in markets with $20+$ employers offering a fully-insured choice. There is no theoretical reason to restrict the switching analysis in this way; I present results using this subsample to maintain consistency with the rent extraction analysis. The descriptive statistics for the switching variables in both samples are given separately by year in Table 7; 1998 is omitted as the switching variables can only be defined for employermarkets with data in the preceding year. Just over one-third of the observations in the total sample have a carrier switch, and 45 percent have a plan switch. The figures are even higher in the fully-insured sample, with 47 percent of observations switching carriers and 56 percent switching plans. In both samples, there is a marked decline in switching over time. This reflects, at least in part, the declining number of options available.

The results of the switching analysis (Table 8) strongly support the hypothesis that more profitable firms are less likely to switch carriers or plans. The point estimates are slightly larger for carrierswitch, and given the lower mean levels of carrierswitch this translates into larger proportional effects. For example, a 10-percentage-point increase in profit margins in year $t$ is associated with a reduction of roughly 4 percentage points in the propensity to switch carriers between $t+1$ and $t+2$. Given the mean levels of carrierswitch, this corresponds to a decline of more than 10 percent. The planswitch models yield 
somewhat smaller estimates, but both results are quite robust to alternative specifications as well as the different data samples.

The advantage of the linear probability models is the ability to control for a variety of fixed effects. However, a binary outcome measure does not permit a distinction among types of switching. Plan deletion should be much more responsive to profits than plan addition, which should not generally impose a cost on employees (apart from those responsible for benefits administration). To refine the analysis, I therefore estimate multinomial logit models using two multivalued outcome measures, carrierchange and planchange, which correspond directly to carrierswitch and planswitch. The outcomes are no change (the base outcome), add only, drop only, and add and drop. To the extent profitable firms avoid carrier and/or plan changes in general all three outcomes will be less likely for such firms. However, if the mechanism described above is correct, changes that include deletions should be the most sensitive to profits.

In these models, I include only lagged profits and year fixed effects as explanatory variables. Estimating coefficients for additional fixed effects is neither computationally feasible nor conceptually appropriate given the data. An employer fixed effect, for example, would control for the propensity for every employer to select every outcome, leaving only within-employer, within-outcome variation to identify the parameters for each choice. Given the switching results presented in Table 8 are generally insensitive to the inclusion of various fixed effects, the pattern of coefficients and predicted outcomes for a parsimonious multinomial model should yield accurate qualitative conclusions.

Table 9 reports the results in the form of risk ratios for each outcome relative to the base outcome of no change, using carrierchange in the top panel and planchange in the bottom panel. Both models are estimated on the combined SI and FI sample (results are similar with the FI sample, and available upon request.) All of the ratios are significantly less than 1, indicating that more profitable firms are less likely to make any changes to their carriers or plans. However, the relative risk ratio for adding is four to five times as great as that for deleting or adding and deleting, which are fairly close in size; this difference is also 
statistically significant. To put the results into the context of outcome probabilities, at the bottom of each panel I present the realized probabilities together with the mean of predicted probabilities assuming a profit shock of .10 for each employer. Using the results from the carrierchange model, the probability of adding a plan declines from .090 to $.085(6 \%)$, the probability of deleting a plan declines from .105 to $.083(21 \%)$, and the probability of adding and deleting a plan declines from .160 to .133 (17\%). These results suggest employers are especially reluctant to drop healthplans when profitable, a finding that supports the hypothesis that profits act to raise employers' switching costs.

Next, I turn to the question of how the propensity of profitable firms to switch healthplans varies by the market structure of the local insurance industry. Conditional on the same positive profit shock, if firms in markets with a greater number of insurers are more likely to switch, the shock to switching costs may be lower in these markets. Under this scenario, the fact that insurers extract less of the profit shock in such markets may be attributable to a smaller effect of the profit shock on switching costs in these markets. The results in Table 9 suggest the exact opposite: firms in more competitive markets are less likely to switch carriers in the wake of a profit shock. ${ }^{43}$ (Results are presented for linear probability models using carrierswitch as the dependent variable and estimated using the entire sample; results for other samples, dependent variables, and models are similar.) As demonstrated by the model, this result suggests that higher bargaining power of insurers is the likelier source of greater rent extraction in markets with small numbers of carriers. The result is also consistent with the rent-extraction finding: profitable firms face the greatest premium increases in concentrated insurance markets, and are likeliest (ceteris paribus) to shop around in these markets.

The Online Appendix presents the results of an additional analysis examining the benefits to employers of switching. If switching costs are the main reason profitable employers are willing to pay more for health insurance, then among the set of employers who do switch profit shocks should not be associated with higher premiums, ceteris paribus. The

\footnotetext{
${ }^{43}$ In all specifications presented Table 8, two-sided t-tests easily reject equality of the coefficients on lagged profits*(1-4 carriers) and lagged profits*( $>10$ carriers).
} 
analysis is consistent with this hypothesis: new plans are cheaper than old plans, and among this set of "switchers," there is a negative relationship between profit shocks and premium growth. $^{44}$

\section{Discussion and Conclusions}

The U.S. healthcare system relies heavily on private insurance companies to manage healthcare consumption and payments to providers. Private insurers' share of health expenditures in the U.S. stood at $35 \%$ in 2000, more than twice that of the next-highest share (15\% in The Netherlands). ${ }^{45}$ In 2007 , expenditures by private insurers were estimated at $\$ 676$ billion, up from $\$ 295$ billion in 1993 . $^{46}$

Although advocates of the private insurance system usually appeal to the virtues of competition, to date there is little empirical evidence to support the assumption of robust competition among insurance carriers. ${ }^{47}$ Prior studies are limited by poor data quality, inaccurate measures of competition (typically limited to a broad measure of HMO activity), a lack of exogenous variation in these measures, and inappropriate market definitions.

With the benefit of high-quality micro panel data on a large sample of fully-insured group healthplans, I find insurers have sufficient market power to negotiate higher premiums disproportionately for firms experiencing positive profit shocks. This result stands in stark contrast to that predicted in the competitive setting, where private insurers vying for each contract bid down the premium until it has no relation to the employer's willingness to pay.

\footnotetext{
${ }^{44}$ It is important to note that the switching decision cannot be assumed exogenous to the new premiums. That is, employers who switch probably do so in order to get attractive deals. The results of this supplemental analysis suggest profitable employers may insist on particularly attractive deals in order to switch.

${ }^{45}$ OECD Health Data, 2003, $2^{\text {nd }}$ edition.

${ }^{46}$ Source: Centers for Medicare and Medicaid Services, Office of the Actuary, National Health Statistics Group. http://www.cms.hhs.gov/NationalHealthExpendData/downloads/proj2007.pdf. These figures do not include estimates of insurer profits and costs, i.e., they do not represent total premiums collected. Data on total premiums is not readily available.

${ }^{47}$ As insurer consolidation continues apace, concerns are mounting. For example, in 2006 the Kaiser Family Foundation's Annual Survey of Employer Health Benefits asked employers to rate the role of "higher insurance company profits" in contributing to health insurance premiums; this is the first time insurance company profits have been included in the list of choices. 45 percent of firms reported the contribution to be "a lot," second only to higher spending for prescription drugs (66 percent). (Kaiser Family Foundation and Health Research and Educational Trust Employer Health Benefits 2006 Annual Survey, Exhibit 12.3)
} 
Indeed, I find this de facto price discrimination is most pronounced in markets with a small number of insurance carriers. Additional analyses reveal employers are less willing to switch insurers after they experience positive profit shocks, a phenomenon that affords incumbent insurers the opportunity to negotiate larger price increases where competition is scarce. Collectively, the results challenge the assumption that U.S. health insurance markets are highly competitive.

The welfare implications of the specific behavior I document are likely to be negative. In a homogeneous product market, if quantity transacted does not increase and consumer and producer surplus are equally valued, price discrimination reduces welfare. In the setting I consider, the quantity of insurance consumed is unlikely to have changed much. Large firms almost always offer insurance, and takeup by employees in these firms is extremely insensitive to changes in the premiums they are charged (Gruber and Washington 2005). Of course, this setting deviates from the homogenous setting in many ways and theoretically surplus gains from discrimination remain possible (e.g. employees in unprofitable firms may benefit more from the reduction in their premiums than employees in profitable firms lose from the increases they face).

Of greater interest are the broad welfare implications of market power in the health insurance industry, of which price discrimination is but one manifestation. Although the analysis I perform does not lend itself to the quantification of market power, the point estimates suggest it is nontrivial. In markets with 6 or fewer carriers, a 10-percentage-point increase in the after-tax return on assets (approximately the standard deviation of this measure during the 2001 recession) is followed by a 1.2-percent increase in health insurance premiums. Given operating margins for insurers are generally less than 5 percent, this figure is rather impressive. ${ }^{48}$ Importantly, in my sample the share of covered employees in markets with 6 or fewer carriers increased dramatically over time, from 7 percent in 1998 to 23 percent in 2005. Concentration has only increased since. Thus, the evidence indicates health

\footnotetext{
${ }^{48}$ Citing research by Sanford Bernstein, an investment research firm, The Economist reported that 2003 operating margins were 5.1 percent, "possibly an all-time high" as of the time of reporting (6/12/2004, p. 71). Insurers derive a sizeable share of total profits (which exceed operating margins) via the float: they earn interest on premium dollars before they are paid to reimburse claims.
} 
insurers are exercising market power in an increasing number of geographic markets. Quantifying the degree of market power and assessing its impacts on healthcare outcomes and costs is an important agenda for future research.

The most immediate implications of this analysis are twofold. First, federal and state governments may want to carefully assess the degree of competition in the relevant insurance markets before expanding the role of the private sector in health-insurance provision. Second, proposed consolidations in this industry may warrant greater scrutiny by antitrust enforcement agencies than has taken place to date. In particular, the bargaining strength of insurers vis-à-vis employers appears to be especially strong where 6-8 or fewer major carriers are present. The results also suggest analyses of employer switching costs are critical inputs for assessments of the competitive effects of combinations in this sector. Remedies that reduce switching costs, such as prohibitions on multi-year, exclusive contracts between insurers and healthcare providers, may lessen the competitive impact of consolidations in concentrated markets.

Finally, research on the extent to which uncompetitive markets are contributing to higher healthcare costs - and potentially more important - to slower innovation in healthcare management and delivery of care - would help to inform the public debate over healthcare reform. 


\section{References}

Armstrong, Mark (2006), "Recent Developments in the Economics of Price Discrimination," Advances in Economics and Econometrics: Theory and Applications, Ninth World Congress, eds. Blundell, Newey and Persson, Cambridge University Press.

Baltagi, Badi H. and Ping X. Wu (1999), "Unequally Spaced Panel Data Regressions with AR(1) Disturbances," Econometric Theory 15: 814-823.

Blanchflower, David G., Andrew J. Oswald, and Peter Sanfey (1996), "Wages, Profits, and Rent-Sharing," Quarterly Journal of Economics, Vol. 111(1): 227-251.

Borenstein, Severin and Joseph Farrell (2007), "Do Investors Forecast Fat Firms? Evidence from the Gold Mining Industry”, RAND Journal of Economics, 38(3): 626-647.

Bresnahan, T. F. and Reiss, P. C. (1991), "Entry and Competition in Concentrated Markets," Journal of Political Economy, 99(5): 977-1009.

Cooper, Philip and Kosali I. Simon (2007), “Trends and Determinants of Self Insuring Employer Health Benefits, 1997-2004," Cornell University mimeo.

Dranove, David, Anne Gron, and Michael Mazzeo, "Differentiation and Competition in HMO Markets," Journal of Industrial Economics, LI(4): 433-454.

Dickens, W. T. and Lawrence F. Katz (1987), "Inter-Industry Wage Differences and Theories of Wage Determination," in K. Lang and J. Leonard, eds., Unemployment and the Structure of Labor Markets (Blackwell), 48-89.

Duggan, Mark (2004), "Does Contracting Out Increase the Efficiency of Government Programs? Evidence from Medicaid HMOs," Journal of Public Economics, December 2004: 2549-2572.

Duggan, Mark and Fiona Scott Morton (2008), "The Effect of Medicare Part D on Pharmaceutical Prices and Utilization,” NBER Working Paper 13917.

Ethoven, A.C. (1978), "Consumer-Choice Health plan (second of two parts). A nationalhealth-insurance proposal based on regulated competition in the private sector," New England Journal of Medicine: 298(13): 709-20.

Federal Trade Commission and Department of Justice (2004), "Improving Health Care: A Dose of Competition: A Report by the Federal Trade Commission and the Department of Justice." 
Ginsburg, Paul B; Bardley C. Strunk, Michelle I. Banker, and John P. Cookson, "Tracking Health Care Costs: Continued Stability But at High Rates in 2005," Health Affairs web exclusive, 25, no. 6 (2006): w486-w495

Gruber, Jonathan (1994), “The Incidence of Mandated Maternity Benefits," American Economic Review, 84(3): 622-641.

Ho, Katherine (2009), "Insurer-Provider Networks in the Medical Care Market," American Economics Review, forthcoming.

Katz, Lawrence F., and Lawrence H. Summers. 1989. Industry rents and industrial policy. Brookings papers on economic activity: Microeconomics, 209-75.

Marquis, M. Susan and Stephen H. Long (2000), "Who Helps Employers Design Their Health Insurance Benefits?” Health Affairs, 19(1): 133-138.

Pauly, Mark (1998), Health Benefits at Work: An Economic and Political Analysis of Employment-based Health Insurance. Ann Arbor: University of Michigan Press, 1997.

Robinson, Jamie (2004), "Consolidation and The Transformation Of Competition In Health Insurance," Health Affairs, 23(6): 11-24.

Robinson, Jamie (2006), "The Commercial Health Insurance Industry in an Era of Eroding Employer Coverage," Health Affairs, 25(6): 1475-1486.

Scanlon, Dennis P., Chernew, Michael, and Woolton Lee (2006), "Competition in Health Insurance Markets: Limitations of Current Measures for Policy Analysis," Medical Care Research and Review, 63(6): 37S-55S.

Spulber, Daniel (1979), "Noncooperative Equilibrium with Price Discriminating Firms," Economic Letters, 4:221-227.

Stole, Lars (2005), "Price Discrimination in Competitive Environments," forthcoming in Armstrong, M. and Porter R.H. (eds), Handbook of Industrial Organization vol.3 (North-Holland, Amsterdam).

Wennberg, J.E., Elliot Fisher, and Jonathan Skinner (2002), "Geography and the Debate Over Medicare Reform,” Health Affairs 21(2) web exclusive: W96-W114.

Wholey, Douglas, Roger Feldman, and Jon B. Christianson (1995), "The Effect of Market Structure on HMO Premiums," Journal of Health Economics 14: 81-105. 
Figure 1. Nonelderly Population with Private Insurance Coverage, 1998-2005

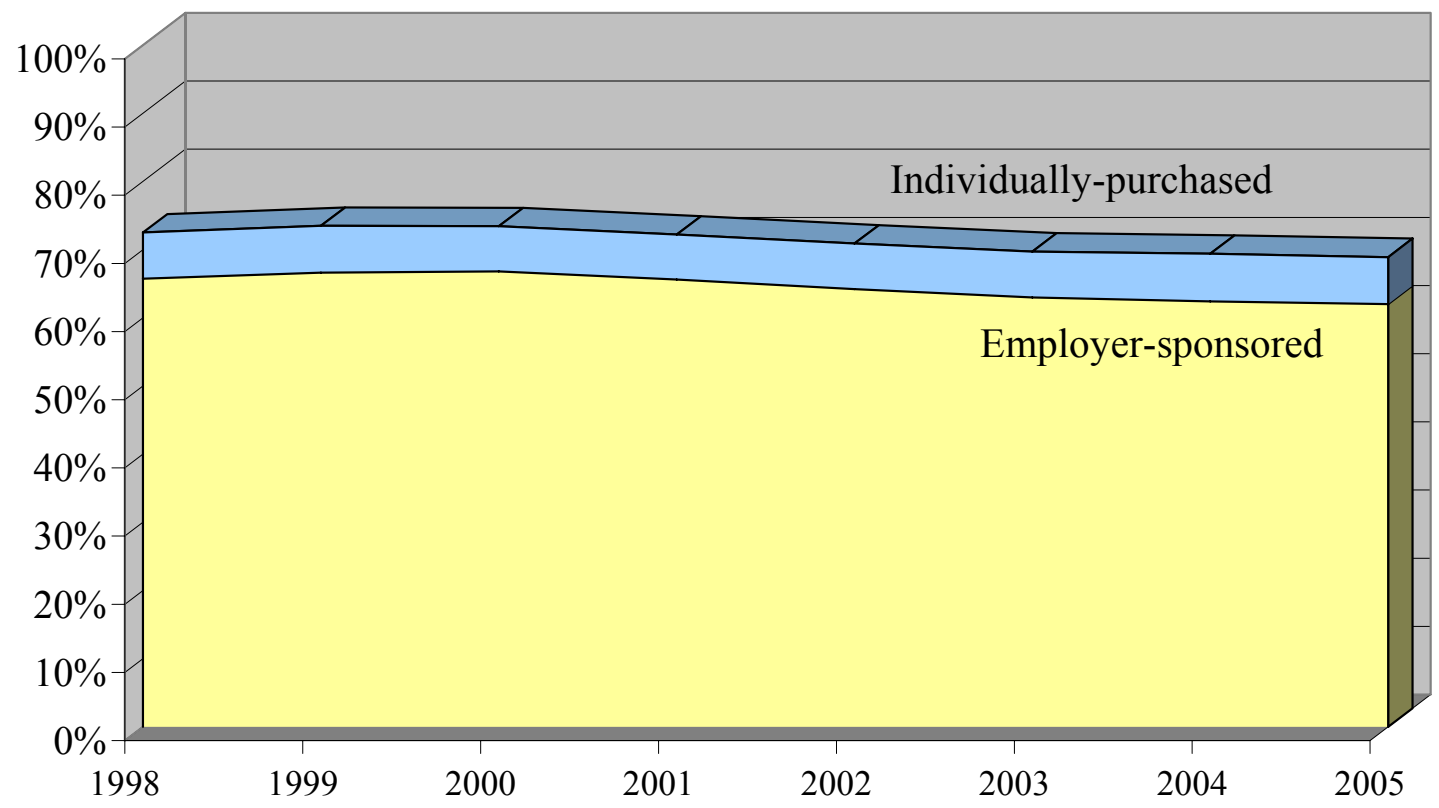

Source: Enployee Benefit Research Institute estimates using the Current Population Survey, March 1998-2006 Supplements. 
Figure 2. Growth in Annual Health Insurance Premiums, 1999-2005

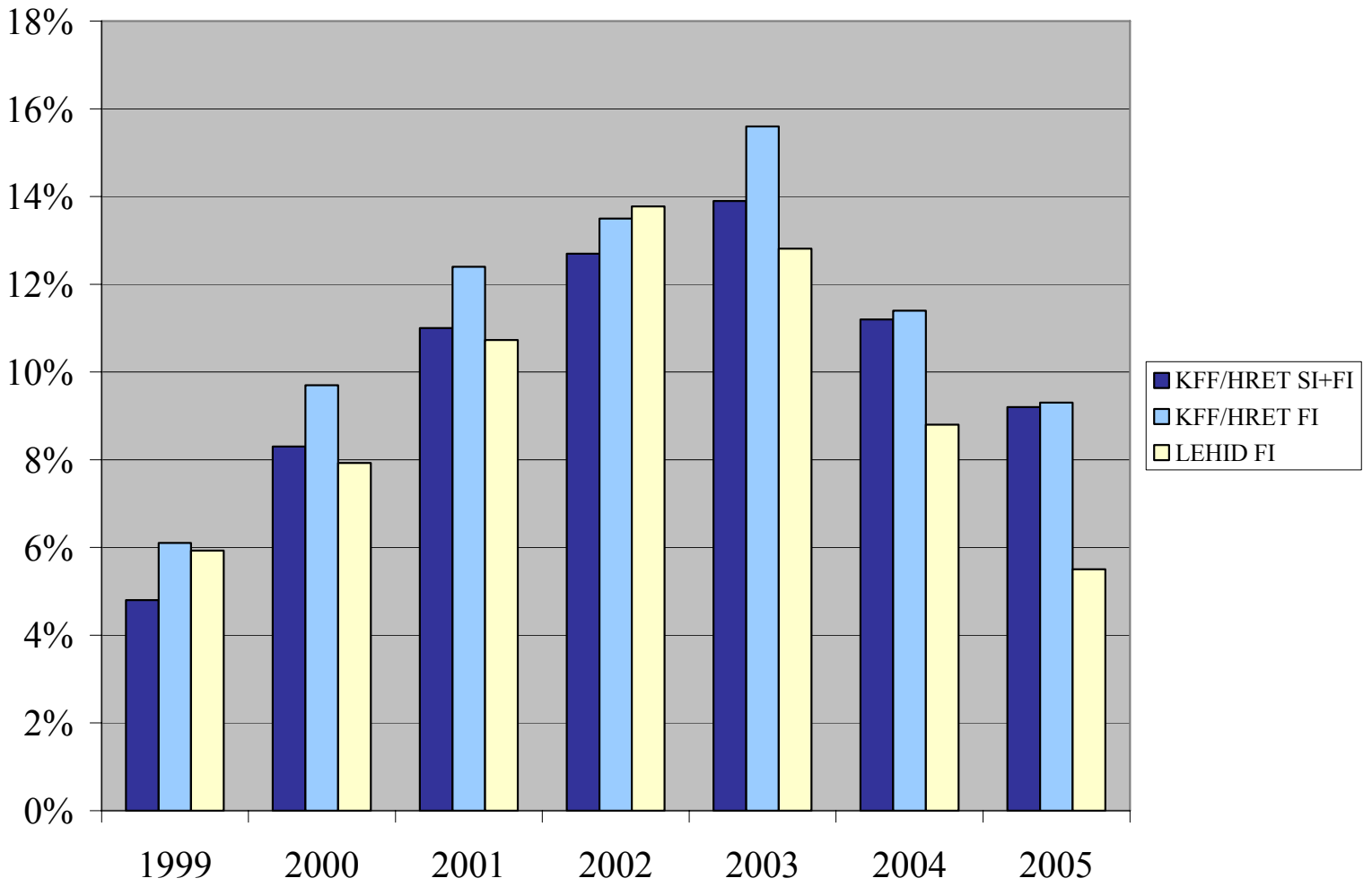

Notes: KFF/HRET growth based on average premiums for a family of four, as reported by survey participants. "FI" denotes fully-insured plans, while "SI" denotes self-insured plans. "Premiums" for SI plans reflect employers' estimates of the cost of coverage. LEHID figures are based on average premiums per covered employee, weighted to reflect the number of covered employees in each plan. 
Figure 3. Percent of Workers Covered in Fully-Insured Health Plans, 1998-2005

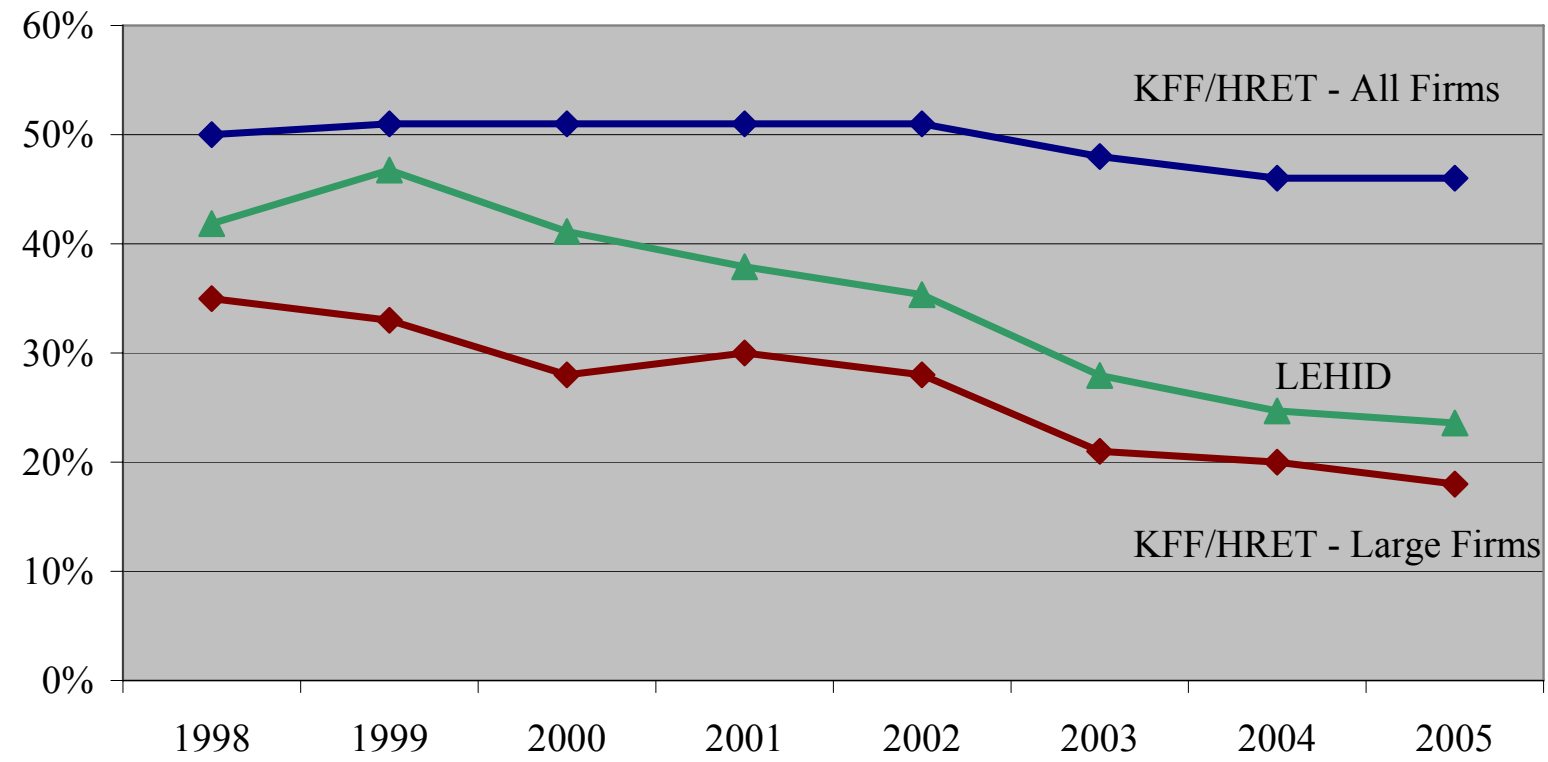

Source: KFF/HRET Survey of Employer-Sponsored Health Benefits, authors' tabulations of LEHID Notes: KFF/HRET "Large" Firms have more than 5,000 employees 
Figure 4. Geographic Distribution of Employees in LEHID Sample

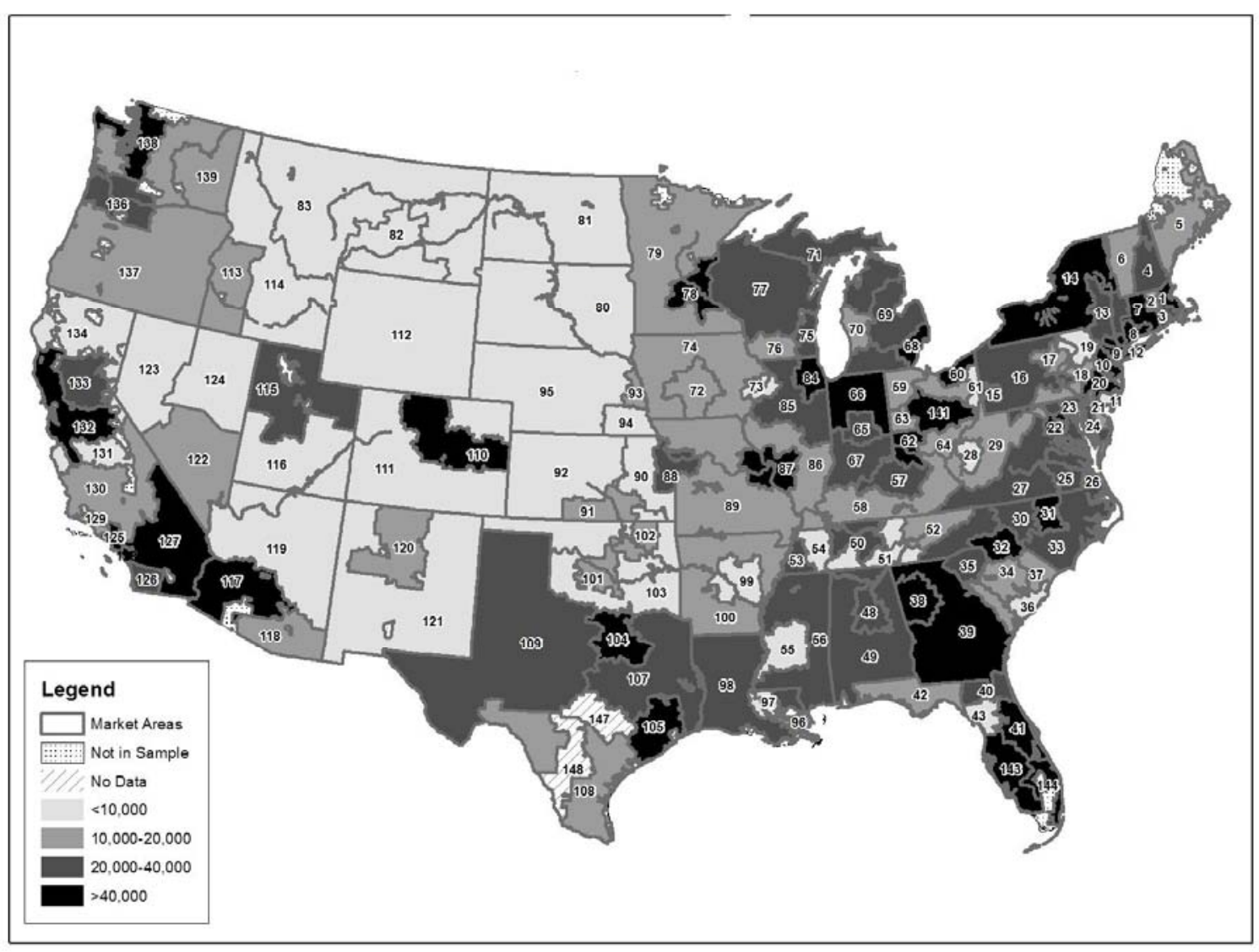

Notes: Data reflects averages across the period 1998-2005. Canyons and other inhabitable areas are outlined in gray. 
Figure 5. Distribution of Markets by Number of Full Insurance Carriers, 1998-2005

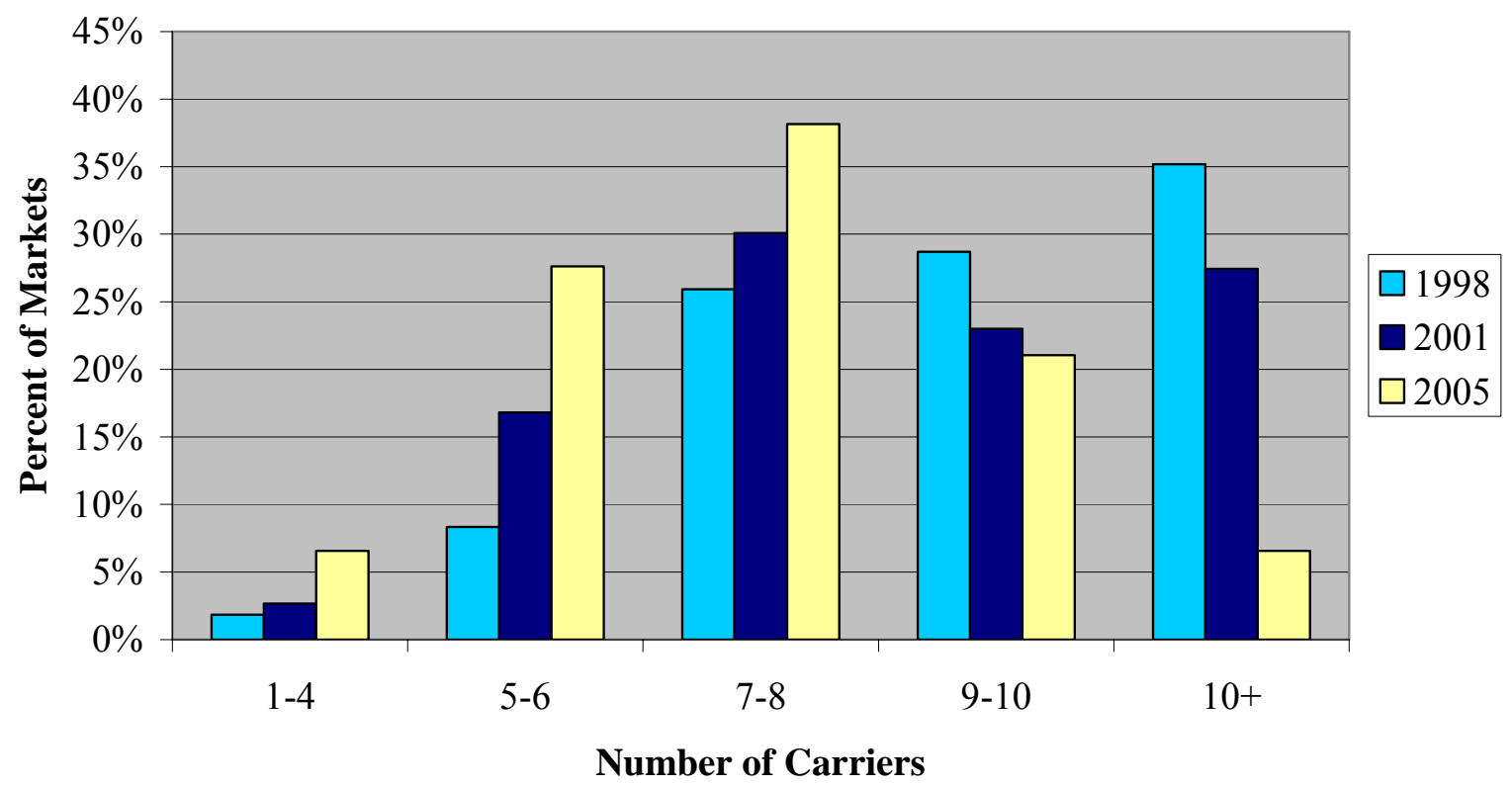

Source: Author's tabulations, LEHID-FI sample. The number of markets is 108 (1998) 113 (2001) and 76 (2005). 
Table 1. Descriptive Statistics, LEHID FI-Compustat Sample

\begin{tabular}{lcccccccc}
\hline & 1998 & 1999 & 2000 & 2001 & 2002 & 2003 & 2004 & 2005 \\
\hline & & & & & & & & \\
Premium (\$) & 3686 & 3964 & 4172 & 4670 & 5445 & 5959 & 6808 & 7222 \\
& 1016 & 923 & 957 & 1104 & 1378 & 1450 & 1885 & 2124 \\
Enrollment (\# employees) & 170 & 174 & 167 & 189 & 191 & 170 & 182 & 203 \\
& 487 & 491 & 416 & 535 & 516 & 387 & 553 & 616 \\
Lagged profit margin & 0.050 & 0.054 & 0.059 & 0.061 & 0.061 & 0.028 & 0.028 & 0.043 \\
& 0.036 & 0.041 & 0.052 & 0.050 & 0.060 & 0.114 & 0.102 & 0.051 \\
Demographic factor & 2.28 & 2.26 & 2.21 & 2.25 & 2.29 & 2.28 & 2.41 & 2.36 \\
& 0.43 & 0.39 & 0.37 & 0.38 & 0.38 & 0.40 & 0.40 & 0.43 \\
Plan design & 1.12 & 1.13 & 1.11 & 1.13 & 1.12 & 1.11 & 1.10 & 1.07 \\
& 0.05 & 0.03 & 0.04 & 0.03 & 0.04 & 0.04 & 0.08 & 0.06 \\
Plan type & & & & & & & & \\
HMO & $88.9 \%$ & $91.8 \%$ & $93.2 \%$ & $92.0 \%$ & $91.0 \%$ & $93.5 \%$ & $91.1 \%$ & $92.1 \%$ \\
Indemnity & $2.2 \%$ & $0.3 \%$ & $0.0 \%$ & $0.1 \%$ & $1.4 \%$ & $0.0 \%$ & $1.0 \%$ & $0.2 \%$ \\
POS & $6.9 \%$ & $6.6 \%$ & $4.6 \%$ & $4.9 \%$ & $2.7 \%$ & $3.7 \%$ & $3.6 \%$ & $4.8 \%$ \\
PPO & $2.0 \%$ & $1.4 \%$ & $2.2 \%$ & $3.1 \%$ & $4.9 \%$ & $2.8 \%$ & $4.3 \%$ & $2.8 \%$ \\
Unemployment Rate & & & & & & & & \\
AAPCC (\$) & 0.044 & 0.041 & 0.039 & 0.047 & 0.058 & 0.060 & 0.055 & 0.051 \\
& 0.016 & 0.014 & 0.010 & 0.010 & 0.010 & 0.011 & 0.011 & 0.010 \\
Number of employers & 5299 & 5213 & 5548 & 6017 & 6541 & 6859 & 7302 & 7744 \\
Number of markets & 923 & 885 & 966 & 1032 & 1155 & 1168 & 1146 & 1216 \\
Number of Observations & & & & & & & 136 & 137 \\
\hline & 125 & 136 & 129 & 149 & 156 & 184 & 135 & 76 \\
& 108 & 117 & 109 & 113 & 110 & 101 & 83 & 759 \\
\hline
\end{tabular}

Notes: All statistics are unweighted. The unit of observation is the employer-market-carrier-plan type-year. Standard deviations in italics. Premiums are reported in nominal dollars. Profit margin = after-tax return on assets and is lagged two years. Demographic factor reflects age, gender, and family size for enrollees. Plan design measures the generosity of benefits. Both are constructed by the data source and exact formulae are not available. The unemployment rate and Average Adjusted Per Capita Cost (AAPCC) per Medicare beneficiary are reported at the county-year level by BLS and CMS, respectively, and matched to the market-year as described in the text. 
Table 2. The Relationship between Employer Profits and Health Insurance Premiums

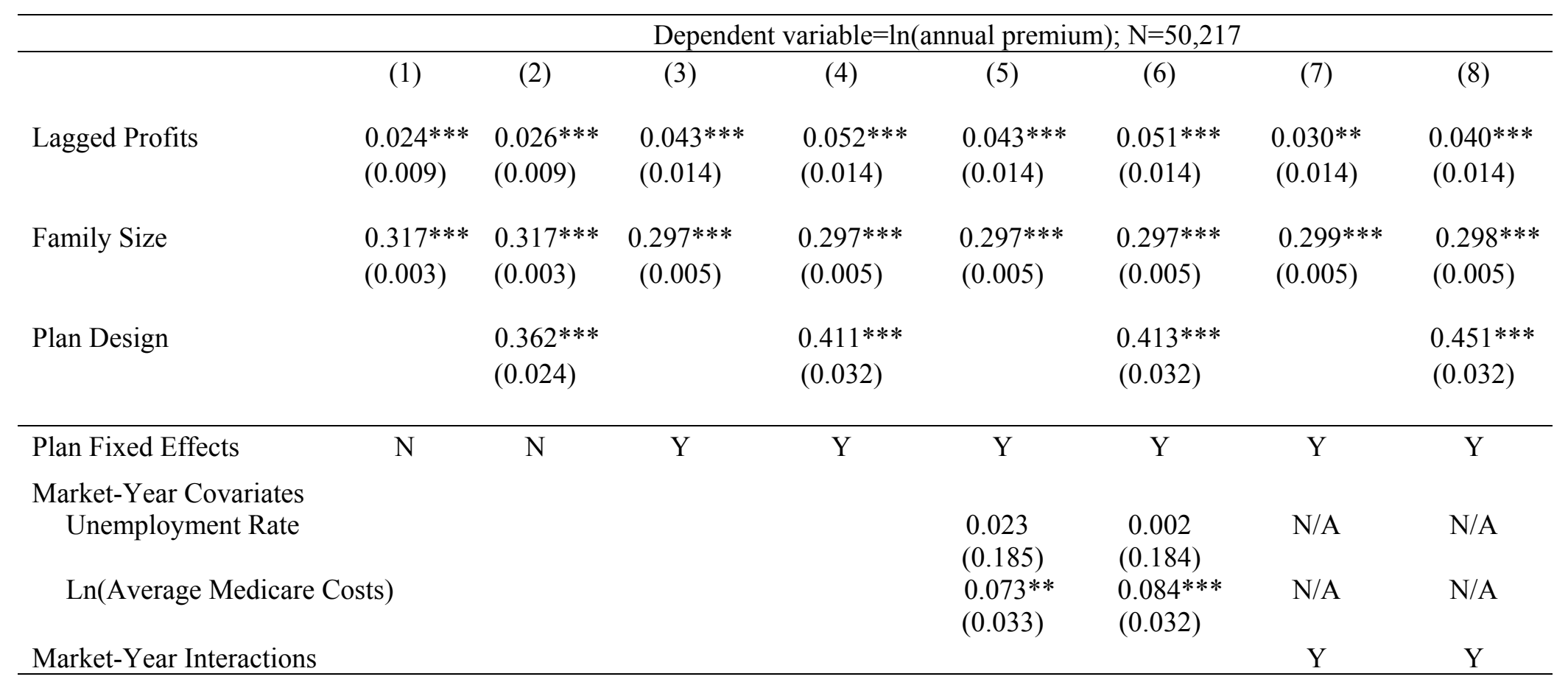

$* \mathrm{p}<0.10, * * \mathrm{p}<0.05, * * * \mathrm{p}<0.01$

Notes: Models are estimated using the LEHID FI-Compustat Sample. The unit of observation is the employer-market-carrier-plan type-year. Specifications correspond to equation (1) in the text, and are estimated by FGLS to account for serial correlation of errors among observations of the same employer-marketcarrier-plan type (or "plan"). All specifications include fixed effects for employer, market, carrier, plan type, year, plan type-year, and employer-market. 
Table 3. The Relationship between Employer Profits and Health Insurance Premiums, By Market Structure of the Insurance Sector

\begin{tabular}{|c|c|c|c|c|}
\hline & \multicolumn{4}{|c|}{ Dependent variable $=\ln ($ annual premium $) ; \mathrm{N}=50,217$} \\
\hline & (1) & (2) & (3) & (4) \\
\hline \multicolumn{5}{|l|}{ Lagged Profits* } \\
\hline \multirow[t]{2}{*}{$<=4$ carriers } & $0.151 * * *$ & $0.148 * *$ & $0.145^{* *}$ & $0.168 * *$ \\
\hline & $(0.058)$ & $(0.072)$ & $(0.072)$ & $(0.075)$ \\
\hline \multirow{2}{*}{ 5-6 carriers } & $0.047 *$ & $0.092 * *$ & $0.092 * *$ & 0.060 \\
\hline & $(0.027)$ & $(0.042)$ & $(0.042)$ & $(0.043)$ \\
\hline \multirow[t]{2}{*}{ 7-8 carriers } & $0.034 * * *$ & $0.056^{* * *}$ & $0.055 * * *$ & $0.042 * *$ \\
\hline & $(0.012)$ & $(0.018)$ & $(0.018)$ & $(0.018)$ \\
\hline \multirow[t]{2}{*}{ 9-10 carriers } & $0.013 * *$ & $0.043 * *$ & $0.042 * *$ & $0.034 *$ \\
\hline & $(0.014)$ & $(0.019)$ & $(0.019)$ & $(0.019)$ \\
\hline \multirow[t]{2}{*}{$>10$ carriers } & 0.011 & 0.035 & 0.034 & 0.027 \\
\hline & $(0.015)$ & $(0.024)$ & $(0.024)$ & $(0.024)$ \\
\hline \multirow[t]{2}{*}{ Demographic Factor } & $0.317 * * *$ & $0.297 * * *$ & $0.297 * * *$ & $0.298 * * *$ \\
\hline & $(0.003)$ & $(0.005)$ & $(0.005)$ & $(0.005)$ \\
\hline \multirow[t]{2}{*}{ Plan Design } & $0.363 * * *$ & $0.413 * * *$ & $0.415 * * *$ & $0.451 * * *$ \\
\hline & $(0.024)$ & $(0.032)$ & $(0.032)$ & $(0.032)$ \\
\hline Plan Fixed Effects & $\mathrm{N}$ & $\mathrm{Y}$ & $\mathrm{Y}$ & $\mathrm{Y}$ \\
\hline \multicolumn{5}{|l|}{ Market-Year Covariates } \\
\hline \multirow[t]{2}{*}{ Unemployment Rate } & & & -0.109 & $\mathrm{~N} / \mathrm{A}$ \\
\hline & & & $(0.185)$ & \\
\hline \multirow[t]{2}{*}{ Average Medicare Costs } & & & $0.078 * *$ & $\mathrm{~N} / \mathrm{A}$ \\
\hline & & & $(0.033)$ & \\
\hline Market-Year Interactions & $\mathrm{N}$ & $\mathrm{N}$ & $\mathrm{N}$ & $\mathrm{Y}$ \\
\hline p-values from $\mathrm{H}_{0}: \gamma_{1,1}=\gamma_{1,5} \mathrm{H}_{1}: \gamma_{1,1}>\gamma_{1,5}$ & .01 & .07 & .07 & .04 \\
\hline
\end{tabular}

$* \mathrm{p}<0.10, * * \mathrm{p}<0.05, * * * \mathrm{p}<0.01$

Notes: Models are estimated using the LEHID FI-Compustat Sample. The unit of observation is the employer-market-carrier-plan type-year. Specifications correspond to equation (2) in the text, and are estimated by FGLS to account for serial correlation of errors among observations of the same employermarket-carrier-plan type (or "plan"). All specifications include fixed effects for employer, market, carrier, plan type, year, number of carrier category, plan type-year, and employer-market. 
Table 4. The Relationship between Employer Profits and Health Insurance Premiums, By Market Structure of the Insurance Sector Controlling for Differences in Markup for Plan Design

\begin{tabular}{|c|c|c|c|c|}
\hline & \multicolumn{4}{|c|}{ Dependent variable $=\ln ($ annual premium $) ; \mathrm{N}=50,217$} \\
\hline & (1) & (2) & (3) & (4) \\
\hline \multicolumn{5}{|l|}{ Lagged Profits* } \\
\hline \multirow[t]{2}{*}{$<=4$ carriers } & $0.154 * * *$ & $0.143 * *$ & $0.141 * *$ & $0.162 * *$ \\
\hline & $(0.058)$ & $(0.072)$ & $(0.072)$ & $(0.075)$ \\
\hline \multirow[t]{2}{*}{ 5-6 carriers } & $0.046^{*}$ & $0.091 * *$ & $0.092 * *$ & 0.059 \\
\hline & $(0.027)$ & $(0.042)$ & $(0.042)$ & $(0.043)$ \\
\hline \multirow[t]{2}{*}{$7-8$ carriers } & $0.034 * * *$ & $0.056 * * *$ & $0.055 * * *$ & $0.041 * *$ \\
\hline & $(0.012)$ & $(0.018)$ & $(0.018)$ & $(0.018)$ \\
\hline \multirow[t]{2}{*}{ 9-10 carriers } & $0.013 * *$ & $0.043 * *$ & $0.042 * *$ & $0.034 *$ \\
\hline & $(0.014)$ & $(0.019)$ & $(0.019)$ & $(0.019)$ \\
\hline \multirow[t]{2}{*}{$>10$ carriers } & 0.011 & 0.035 & 0.034 & 0.027 \\
\hline & $(0.015)$ & $(0.024)$ & $(0.024)$ & $(0.024)$ \\
\hline \multicolumn{5}{|l|}{ Plan Design* } \\
\hline \multirow[t]{2}{*}{$<=4$ carriers } & $0.429 * * *$ & $0.328 * * *$ & $0.333 * * *$ & $0.280 * *$ \\
\hline & $(0.071)$ & $(0.092)$ & $(0.092)$ & $(0.109)$ \\
\hline \multirow[t]{2}{*}{ 5-6 carriers } & $0.422 * * *$ & $0.419 * * *$ & $0.420 * * *$ & $0.448 * * *$ \\
\hline & $(0.048)$ & $(0.055)$ & $(0.055)$ & $(0.061)$ \\
\hline \multirow[t]{2}{*}{$7-8$ carriers } & $0.380 * * *$ & $0.401 * * *$ & $0.405 * * *$ & $0.436^{* * *}$ \\
\hline & $(0.034)$ & $(0.041)$ & $(0.041)$ & $(0.043)$ \\
\hline \multirow[t]{2}{*}{ 9-10 carriers } & $0.323 * * *$ & $0.435 * * *$ & $0.434 * * *$ & $0.482 * * *$ \\
\hline & $(0.034)$ & $(0.041)$ & $(0.041)$ & $(0.042)$ \\
\hline \multirow[t]{2}{*}{$>10$ carriers } & $0.358 * * *$ & $0.415^{* * *}$ & $0.417 * * *$ & $0.462 * * *$ \\
\hline & $(0.039)$ & $(0.051)$ & $(0.051)$ & $(0.054)$ \\
\hline \multirow[t]{2}{*}{ Demographic Factor } & $0.317 * * *$ & $0.297 * * *$ & $0.297 * * *$ & $0.299 * * *$ \\
\hline & $(0.003)$ & $(0.005)$ & $(0.005)$ & $(0.005)$ \\
\hline Plan Fixed Effects & $\mathrm{N}$ & $\mathrm{Y}$ & $\mathrm{Y}$ & $\mathrm{Y}$ \\
\hline \multicolumn{5}{|l|}{ Market-Year Covariates } \\
\hline \multirow[t]{2}{*}{ Unemployment Rate } & & & -0.111 & N/A \\
\hline & & & $(0.185)$ & \\
\hline \multirow[t]{2}{*}{ Average Medicare Costs } & & & $0.077 * *$ & $\mathrm{~N} / \mathrm{A}$ \\
\hline & & & $(0.033)$ & \\
\hline Market-Year Interactions & $\mathrm{N}$ & $\mathrm{N}$ & $\mathrm{N}$ & $\mathrm{Y}$ \\
\hline p-values from $\mathrm{H}_{0}: \gamma_{1,1}=\gamma_{1,5} \mathrm{H}_{1}: \gamma_{1,1}>\gamma_{1,5}$ & .01 & .07 & .08 & .04 \\
\hline
\end{tabular}

$* \mathrm{p}<0.10, * * \mathrm{p}<0.05, * * * \mathrm{p}<0.01$

Notes: Models are estimated using the LEHID FI-Compustat Sample. The unit of observation is the employer-market-carrier-plan type-year. Specifications correspond to equation (2) in the text, and are estimated by FGLS to account for serial correlation of errors among observations of the same employermarket-carrier-plan type (or "plan"). All specifications include fixed effects for employer, market, carrier, plan type, year, number of carrier category, plan type-year, and employer-market. 
Table 5. Robustness Check:

First Differences Specifications

Dependent variable $=\Delta \ln ($ annual premium $) ; \mathrm{N}=25,514$

(1) (2) (3)

\begin{tabular}{|c|c|c|c|c|}
\hline$\Delta$ Lagged Profits & $\begin{array}{l}0.027 * * * \\
(0.010)\end{array}$ & $\begin{array}{l}0.022 * * \\
(0.010)\end{array}$ & & \\
\hline$* \mathrm{I}(<=4$ carriers $)$ & & & $\begin{array}{l}0.125 * * * \\
(0.044)\end{array}$ & $\begin{array}{l}0.152^{* * * *} \\
(0.057)\end{array}$ \\
\hline *I(5-6 carriers $)$ & & & $\begin{array}{l}0.087 * * * \\
(0.024)\end{array}$ & $\begin{array}{l}0.012 \\
(0.029)\end{array}$ \\
\hline *I(7-8 carriers $)$ & & & $\begin{array}{l}0.036^{* * * *} \\
(0.013)\end{array}$ & $\begin{array}{l}0.030 * * \\
(0.013)\end{array}$ \\
\hline *I(9-10 carriers $)$ & & & $\begin{array}{l}0.009 \\
(0.013)\end{array}$ & $\begin{array}{l}0.008 \\
(0.015)\end{array}$ \\
\hline$* \mathrm{I}(>10$ carriers $)$ & & & $\begin{array}{c}0.014 \\
(0.015)\end{array}$ & $\begin{array}{l}0.017 \\
(0.017)\end{array}$ \\
\hline Demographic Factor & $\begin{array}{l}0.289 * * * \\
(0.005)\end{array}$ & $\begin{array}{l}0.290 * * * \\
(0.004)\end{array}$ & $\begin{array}{l}0.289 * * * \\
(0.005)\end{array}$ & $\begin{array}{l}0.290 * * * \\
(0.004)\end{array}$ \\
\hline Plan Design & $\begin{array}{l}0.342 * * * \\
(0.031)\end{array}$ & $\begin{array}{l}0.370 * * * \\
(0.032)\end{array}$ & $\begin{array}{l}0.342 * * * \\
(0.032)\end{array}$ & $\begin{array}{l}0.382 * * * \\
(0.032)\end{array}$ \\
\hline Market-Year Interactions & $\mathrm{N}$ & $\mathrm{Y}$ & $\mathrm{N}$ & $\mathrm{Y}$ \\
\hline
\end{tabular}

$* \mathrm{p}<0.10, * * \mathrm{p}<0.05, * * * \mathrm{p}<0.01$

Notes: Specifications correspond to equation (3) in the text. Models are estimated using the LEHID FICompustat Sample. The unit of observation is the employer-market-carrier-plan type. All specifications include year and plan type-year fixed effects. Specifications (3) and (4) also include fixed effects for the number of carrier categories. Robust standard errors, clustered by employer-market-carrier-plan type, are in parentheses. 
Table 6. Descriptive Statistics (Switching Analysis)

\begin{tabular}{lccccccc}
\hline & 1999 & 2000 & 2001 & 2002 & 2003 & 2004 & 2005 \\
\hline FI and SI combined & & & & & & & \\
& & & & & & & \\
Carrierswitch & $42 \%$ & $45 \%$ & $37 \%$ & $37 \%$ & $32 \%$ & $33 \%$ & $25 \%$ \\
Planswitch & $51 \%$ & $53 \%$ & $50 \%$ & $47 \%$ & $41 \%$ & $44 \%$ & $34 \%$ \\
Lagged profits & 0.06 & 0.06 & 0.06 & 0.06 & 0.04 & 0.03 & 0.04 \\
& 0.05 & 0.06 & 0.04 & 0.05 & 0.09 & 0.10 & 0.06 \\
Number of employers & 142 & 138 & 159 & 168 & 213 & 162 & 166 \\
Number of markets & 136 & 136 & 137 & 137 & 137 & 137 & 137 \\
Number of observations & 5787 & 6009 & 5927 & 7213 & 8235 & 6741 & 6634 \\
\hline FI only & & & & & & & \\
& & & & & & & $36 \%$ \\
Carrierswitch & $55 \%$ & $56 \%$ & $49 \%$ & $48 \%$ & $41 \%$ & $32 \%$ \\
Planswitch & $64 \%$ & $64 \%$ & $58 \%$ & $59 \%$ & $50 \%$ & $47 \%$ & $41 \%$ \\
Lagged profits & 0.05 & 0.06 & 0.06 & 0.06 & 0.03 & 0.03 & 0.04 \\
& 0.04 & 0.06 & 0.04 & 0.06 & 0.09 & 0.10 & 0.05 \\
Number of employers & 136 & 129 & 149 & 156 & 184 & 135 & 137 \\
Number of markets & 117 & 109 & 113 & 110 & 101 & 83 & 76 \\
Number of observations & 3051 & 3115 & 2860 & 3093 & 2989 & 1929 & 1706 \\
\hline
\end{tabular}

Notes: All statistics are unweighted. The unit of observation is the employer-market-year. Standard deviations in italics 
Table 7. Switching Analysis

\begin{tabular}{|c|c|c|c|c|c|c|c|c|}
\hline Dependent Variable & carrierswitch & planswitch & carrierswitch & planswitch & carrierswitch & planswitch & carrierswitch & planswitch \\
\hline \multicolumn{9}{|c|}{$F I+$ SI Combined $(N=46,546)$} \\
\hline Lagged Profits & $\begin{array}{l}-0.580 * * * \\
(0.033)\end{array}$ & $\begin{array}{l}-0.516^{* * *} \\
(0.034)\end{array}$ & $\begin{array}{l}-0.584 * * * \\
(0.033)\end{array}$ & $\begin{array}{l}-0.523 * * * \\
(0.034)\end{array}$ & $\begin{array}{l}-0.406 * * * \\
(0.057)\end{array}$ & $\begin{array}{l}-0.234 * * * \\
(0.059)\end{array}$ & $\begin{array}{l}-0.340 * * * \\
(0.063)\end{array}$ & $\begin{array}{c}-0.162 * * \\
(0.064)\end{array}$ \\
\hline Market-Year FEs & $\mathrm{N}$ & $\mathrm{N}$ & $\mathrm{Y}$ & $\mathrm{Y}$ & $\mathrm{Y}$ & $\mathrm{Y}$ & $\mathrm{Y}$ & $\mathrm{Y}$ \\
\hline Employer FEs & $\mathrm{N}$ & $\mathrm{N}$ & $\mathrm{N}$ & $\mathrm{N}$ & $\mathrm{Y}$ & $\mathrm{Y}$ & $\mathrm{N} / \mathrm{A}$ & $\mathrm{N} / \mathrm{A}$ \\
\hline Employer-Market FEs & $\mathrm{N}$ & $\mathrm{N}$ & $\mathrm{N}$ & $\mathrm{N}$ & $\mathrm{N}$ & $\mathrm{N}$ & $\mathrm{Y}$ & $\mathrm{Y}$ \\
\hline \multicolumn{9}{|l|}{ FI Sample $(N=18,743)$} \\
\hline Lagged Profits & $\begin{array}{l}-0.528 * * * \\
(0.054)\end{array}$ & $\begin{array}{l}-0.423 * * * \\
(0.054)\end{array}$ & $\begin{array}{l}-0.534 * * * \\
(0.054)\end{array}$ & $\begin{array}{l}-0.432 * * * \\
(0.054)\end{array}$ & $\begin{array}{l}-0.405 * * * \\
(0.054)\end{array}$ & $\begin{array}{l}-0.207 * * \\
(0.054)\end{array}$ & $\begin{array}{l}-0.418 * * * \\
(0.104)\end{array}$ & $\begin{array}{l}-0.167 \\
(0.103)\end{array}$ \\
\hline Market-Year FEs & $\mathrm{N}$ & $\mathrm{N}$ & $\mathrm{Y}$ & $\mathrm{Y}$ & $\mathrm{Y}$ & $\mathrm{Y}$ & $\mathrm{Y}$ & $\mathrm{Y}$ \\
\hline Employer FEs & $\mathrm{N}$ & $\mathrm{N}$ & $\mathrm{N}$ & $\mathrm{N}$ & $\mathrm{Y}$ & $\mathrm{Y}$ & $\mathrm{N} / \mathrm{A}$ & $\mathrm{N} / \mathrm{A}$ \\
\hline Employer-Market FEs & $\mathrm{N}$ & $\mathrm{N}$ & $\mathrm{N}$ & $\mathrm{N}$ & $\mathrm{N}$ & $\mathrm{N}$ & $\mathrm{Y}$ & $\mathrm{Y}$ \\
\hline
\end{tabular}

$* \mathrm{p}<0.10, * * \mathrm{p}<0.05, * * * \mathrm{p}<0.01$

Notes: Specifications correspond to equation (4) in the text. All models include year fixed effects. The unit of observation is the employer-market-year. 
Table 8. Switching Analysis, by Type of Switch

\begin{tabular}{llcc}
\hline Carrier Changes & Add & Drop & Add and Drop \\
\hline Lagged Profits & $.236^{* * *}$ & $.038^{* * *}$ & $.062^{* * *}$ \\
& $(.060)$ & $(.008)$ & $(.012)$ \\
Sample Probability & .090 & .105 & .160 \\
$\begin{array}{l}\text { Predicted Probability with } \\
10 \% \text { Lagged Profit Shock }\end{array}$ & .085 & .083 & .133 \\
\hline & & & \\
\hline Plan Changes & Add & Drop & \\
\hline & $.335^{* * *}$ & $.063^{* * *}$ & $.094^{* * *}$ \\
Lagged Profits & $(.085)$ & $(.013)$ & $(.016)$ \\
& .101 & .108 & .244 \\
Sample Probability & .099 & .090 & .212 \\
\hline $\begin{array}{l}\text { Predicted Probability with } \\
10 \% \text { Lagged Profit Shock }\end{array}$ & & & Add and Drop \\
\hline
\end{tabular}

$* \mathrm{p}<0.10, * * \mathrm{p}<0.05, * * * \mathrm{p}<0.01$

Notes: Entries correspond to relative risk ratios (standard errors) from a multinomial logit model estimated using the carrier change outcome (top panel) and plan change outcome (bottom panel) on the combined FI\& SI sample $(\mathrm{N}=46,546)$. Both models include year fixed effects. 
Table 9. Switching Analysis, By Market Structure of the Insurance Sector

\begin{tabular}{|c|c|c|c|c|}
\hline & \multicolumn{4}{|c|}{ Dependent variable $=$ carrierswitch; $(\mathrm{N}=46,546)$} \\
\hline & (1) & (2) & (3) & (4) \\
\hline \multicolumn{5}{|l|}{ Lagged Profits* } \\
\hline \multirow[t]{2}{*}{$<=4$ carriers } & $-0.187 *$ & $-0.179 *$ & -0.085 & 0.128 \\
\hline & $(0.104)$ & $(0.105)$ & $(0.110)$ & $(0.170)$ \\
\hline \multirow[t]{2}{*}{$5-6$ carriers } & $-0.644 * * *$ & $-0.623 * * *$ & $-0.373 * * *$ & -0.082 \\
\hline & $(0.083)$ & $(0.084)$ & $(0.094)$ & $(0.126)$ \\
\hline \multirow[t]{2}{*}{$7-8$ carriers } & $-0.584 * * *$ & $-0.583 * * *$ & $-0.448 * * *$ & $-0.251 * * *$ \\
\hline & $(0.055)$ & $(0.056)$ & $(0.070)$ & $(0.088)$ \\
\hline \multirow[t]{2}{*}{ 9-10 carriers } & $-0.586^{* * *}$ & $-0.594 * * *$ & $-0.414 * * *$ & $-0.499 * * *$ \\
\hline & $(0.067)$ & $(0.068)$ & $(0.081)$ & $(0.103)$ \\
\hline \multirow[t]{2}{*}{$>10$ carriers } & $-0.737 * * *$ & $-0.750 * * *$ & $-0.521 * * *$ & $-0.760 * * *$ \\
\hline & $(0.075)$ & $(0.076)$ & $(0.088)$ & $(0.119)$ \\
\hline Market-Year FEs & $\mathrm{N}$ & $\mathrm{Y}$ & $\mathrm{Y}$ & $\mathrm{Y}$ \\
\hline Employer FEs & $\mathrm{N}$ & $\mathrm{N}$ & $\mathrm{Y}$ & N/A \\
\hline Employer-Market FEs & $\mathrm{N}$ & $\mathrm{N}$ & $\mathrm{N}$ & $\mathrm{Y}$ \\
\hline
\end{tabular}

${ }^{*} \mathrm{p}<0.10, * * \mathrm{p}<0.05,{ }^{* * *} \mathrm{p}<0.01$

Notes: Models are estimated using the FI \& SI combined sample. All specifications include fixed effects for years and number of carrier categories. The unit of observation is the employer-market-year. 
Appendix Table 1. Number of Employers in LEHID Data, 1998-2005

\begin{tabular}{lcccc}
\hline & & & & \\
At least 1 & At least 1 \\
SI Plan & $\begin{array}{c}\text { least 1 FI } \\
\text { Plan }\end{array}$ \\
\hline 1998 & 194 & 181 & 180 & $93 \%$ \\
1999 & 205 & 197 & 193 & $96 \%$ \\
2000 & 199 & 185 & 191 & $93 \%$ \\
2001 & 242 & 226 & 233 & $93 \%$ \\
2002 & 255 & 226 & 248 & $89 \%$ \\
2003 & 330 & 274 & 315 & $83 \%$ \\
2004 & 246 & 194 & 238 & $79 \%$ \\
2005 & 262 & 203 & 257 & $77 \%$ \\
\hline
\end{tabular}




\section{Appendix A. Substitution between Full and Self-Insurance}

To examine the effect of profit shocks on substitution between full and self-insurance, I begin with the entire sample of healthplans in the market-years included in the LEHID-FI sample. I drop employer-markets that exclusively self-insure in all years, as these employermarkets never appear in the LEHID-FI sample. I also restrict the sample to employer-years with data on lagged profits. I collapse the data to the employer-market-year level, creating employee-weighted averages for all measures. Thus, "premium" is now the average expected outlay per enrollee (whether in an FI or SI plan). I also construct measures such as the number of plans offered, the percent of enrollees in self-insured plans, and the percent of enrollees in each plan type. The final sample contains 38,290 observations from 409 unique employers. Descriptive statistics are presented in Table A1 below.

Table A1. Descriptive Statistics, Employer-Market-Year Sample

\begin{tabular}{lcccccccc}
\hline & 1998 & 1999 & 2000 & 2001 & 2002 & 2003 & 2004 & 2005 \\
\hline Premium (\$) & 3932 & 4079 & 4385 & 4854 & 5573 & 6301 & 6952 & 7463 \\
& 973 & 914 & 944 & 993 & 1174 & 1202 & 1546 & 1684 \\
Enrollment (\# employees) & 616 & 546 & 511 & 583 & 556 & 528 & 554 & 570 \\
& 1865 & 1620 & 1458 & 1792 & 1726 & 1325 & 1391 & 1439 \\
Lagged profit margin & 0.050 & 0.053 & 0.059 & 0.063 & 0.060 & 0.030 & 0.028 & 0.039 \\
& 0.038 & 0.045 & 0.054 & 0.051 & 0.057 & 0.111 & 0.105 & 0.061 \\
Demographic factor & 2.32 & 2.28 & 2.24 & 2.26 & 2.31 & 2.30 & 2.36 & 2.35 \\
& 0.43 & 0.37 & 0.35 & 0.35 & 0.36 & 0.36 & 0.36 & 0.37 \\
Plan design & 1.07 & 1.07 & 1.05 & 1.07 & 1.07 & 1.05 & 1.04 & 1.00 \\
& 0.06 & 0.05 & 0.06 & 0.05 & 0.05 & 0.06 & 0.08 & 0.07 \\
Plan Composition & & & & & & & & \\
\% in self-insured plans & $45.7 \%$ & $44.9 \%$ & $48.7 \%$ & $52.9 \%$ & $55.0 \%$ & $61.7 \%$ & $65.1 \%$ & $69.6 \%$ \\
\% offering self-insured plan & $76.2 \%$ & $83.4 \%$ & $84.6 \%$ & $85.3 \%$ & $84.2 \%$ & $88.4 \%$ & $87.6 \%$ & $91.7 \%$ \\
\# Fully-insured plans & 1.66 & 1.65 & 1.49 & 1.39 & 1.27 & 1.08 & 1.00 & 0.90 \\
\# Self-insured plans & 1.19 & 1.26 & 1.33 & 1.38 & 1.41 & 1.57 & 1.62 & 1.64 \\
\% HMO & $47.5 \%$ & $51.8 \%$ & $50.7 \%$ & $47.8 \%$ & $47.6 \%$ & $44.8 \%$ & $43 \%$ & $50.5 \%$ \\
\% Indemnity & $14.5 \%$ & $12.0 \%$ & $8.2 \%$ & $5.7 \%$ & $4.9 \%$ & $3.1 \%$ & $2.6 \%$ & $1.8 . \%$ \\
\% POS & $21.6 \%$ & $16.7 \%$ & $19.1 \%$ & $17.7 \%$ & $13.2 \%$ & $12.1 \%$ & $13.4 \%$ & $11.2 \%$ \\
\% PPO & $16.4 \%$ & $19.5 \%$ & $22.0 \%$ & $28.8 \%$ & $34.3 \%$ & $40.0 \%$ & $41.0 \%$ & $46.5 \%$ \\
& & & & & & & & $15 \%$ \\
Number of employers & 128 & 137 & 132 & 151 & 160 & 193 & 146 & 150 \\
Number of markets & 108 & 117 & 109 & 113 & 110 & 101 & 83 & 76 \\
Number of Observations & 4222 & 5029 & 4624 & 5255 & 5384 & 5718 & 4047 & 4011 \\
\hline N S S & & & & & & & & \\
\hline
\end{tabular}

Notes: Standard deviations in italics. 
I begin by estimating the following specifications (results in Table A2):

$$
\% \text { self - } \text { insured }_{e m t}=\alpha+\gamma_{1} \text { profit } \text { margin }_{e, t-2}+\tau_{t}+\varsigma_{e m}\left[+\phi_{m t}\right]+\varepsilon_{e m t}
$$

and

$$
\begin{aligned}
\% \text { self }- \text { insured }_{e m t}= & \alpha+\sum_{N C=1}^{5} \gamma_{1, N C} 1(N C)_{m} * \text { profit } \text { margin }_{e, t-2}+\sum_{N C=1}^{4} \lambda_{N C} 1(N C)_{m t} \\
& +\tau_{t}+\varsigma_{e m}\left[+\phi_{m t}\right]+\varepsilon_{e m t}
\end{aligned}
$$

The estimate of $\gamma_{1}$ is negative and marginally significant: firms with profit shocks rely less on self-insured plans. Decomposing this by the market structure of FI carriers reveals no steady pattern or significant differences across different market types. Thus, in spite of the price increases profitable firms face, they are less likely to switch toward self-insurance than are less profitable firms, ceteris paribus. This result is not surprising given the switching analysis, which illustrates the reluctance of profitable firms to make changes to their plan portfolios. Next, I estimate specifications using the log of "premium” (i.e. expected outlay per enrollee) as the dependent variable (results in Table A3):

$$
\begin{aligned}
\ln \left(" \text { premium }^{\prime}\right)_{e m t} & =\alpha+\gamma_{1} \text { profit margin } \\
& +\sum_{j \in J-2} \mu_{j} \% \text { plantype } j_{\text {emt }}+\sum_{j \in J} \psi_{j t}\left(\% \text { oplantype } j_{e m t} * \tau_{t}\right)+\varsigma_{e m} \quad\left[+\varphi_{m t}\right]+\varepsilon_{e m t}
\end{aligned}
$$

and

$$
\begin{aligned}
\ln (\text { " premium" })_{e m t}= & \alpha+\sum_{N C=1}^{5} \gamma_{1, N C} 1(N C)_{m} * \text { profit margin }_{e, t-2}+\sum_{N C=1}^{4} \lambda_{N C} l(N C)_{m t} \\
& +\gamma_{2} \text { demographics }_{\text {emt }}+\gamma_{3} \text { plan design } n_{\text {emt }}+\tau_{t}+\sum_{j \in J} \mu_{j} \% \text { plantype } j_{\text {emt }} \\
& +\sum_{j \in J} \psi_{j t}\left(\% \text { plantype } j_{\text {emt }} * \tau_{t}\right)+\varsigma_{e m}\left[+\varphi_{m t}\right]+\varepsilon_{\text {emt }}
\end{aligned}
$$

Given the level of aggregation, this specification cannot include as rich a set of covariates as that included in the specifications using plan-year data (e.g. there are no controls for the carriers used, and the plan design measure is an average across plan types). However, the similarity of the coefficient estimates for plan design and demographic factor is reassuring. On average, the relationship between profit shocks and premiums is positive and statistically insignificant, but this aggregate coefficient belies significant associations in concentrated 
markets. The magnitudes are quite similar to those obtained using only the fully-insured sample. Given fully-insured plans account for less than half of enrollment in the typical employer-market-year, and self-insured plans did not exhibit similar patterns of premium increases in the falsification exercise, it would seem the coefficient magnitudes should be smaller. However, a direct comparison cannot be made because the effective weighting scheme in the two analyses is quite different. In the main analysis, each fully-insured planyear counts equally; in this supplemental analysis, each employer-market-year (some of which do not even appear in the main analysis) count equally. The conclusion that emerges from these results is that profitable employers do end up paying more for health insurance for the average enrollee in concentrated insurance markets, even once expected outlays from self-insured enrollees are incorporated into the calculation.

Table A2. Effect of Profits on Self-Insurance Rate

\begin{tabular}{|c|c|c|c|c|}
\hline & \multicolumn{4}{|c|}{ Dependent variable $=\%$ self-insured; $\mathrm{N}=38,290$} \\
\hline & (1) & (2) & (3) & (4) \\
\hline \multirow[t]{2}{*}{ Lagged Profits } & $-0.058^{*}$ & $-0.057 *$ & & \\
\hline & $(0.031)$ & $(0.030)$ & & \\
\hline \multirow[t]{2}{*}{$* \mathrm{I}(<=4$ carriers $)$} & & & -0.096 & 0.021 \\
\hline & & & $(0.172)$ & $(0.175)$ \\
\hline \multirow[t]{2}{*}{ *I(5-6 carriers $)$} & & & -0.104 & -0.080 \\
\hline & & & $(0.074)$ & $(0.075)$ \\
\hline \multirow[t]{2}{*}{ *I(7-8 carriers $)$} & & & $-0.074 *$ & -0.065 \\
\hline & & & $(0.042)$ & $(0.042)$ \\
\hline \multirow[t]{2}{*}{ *I(9-10 carriers $)$} & & & -0.019 & -0.009 \\
\hline & & & $(0.048)$ & $(0.048)$ \\
\hline \multirow[t]{2}{*}{$* \mathrm{I}(>10$ carriers $)$} & & & -0.056 & $-0.096^{*}$ \\
\hline & & & $(0.055)$ & $(0.056)$ \\
\hline Market-Year Interactions & $\mathrm{N}$ & $\mathrm{Y}$ & $\mathrm{N}$ & $\mathrm{Y}$ \\
\hline
\end{tabular}


Table A3. The Relationship between Employer Profits and Expected Health Insurance Outlays, By Market Structure of the Insurance Sector

Dependent var $=\ln ($ expected outlays); $\mathrm{N}=38,290$
(1)
(2)
(3)
(4)

\begin{tabular}{|c|c|c|c|c|}
\hline Lagged Profits & $\begin{array}{l}0.016 \\
(0.013)\end{array}$ & $\begin{array}{c}0.014 \\
(0.013)\end{array}$ & & \\
\hline$* \mathrm{I}(<=4$ carriers $)$ & & & $\begin{array}{l}0.152^{* *} \\
(0.062)\end{array}$ & $\begin{array}{l}0.134 * * \\
(0.064)\end{array}$ \\
\hline *I(5-6 carriers $)$ & & & $\begin{array}{l}0.072 * * \\
(0.030)\end{array}$ & $\begin{array}{l}0.068 * * \\
(0.031)\end{array}$ \\
\hline *I(7-8 carriers $)$ & & & $\begin{array}{l}0.025 \\
(0.017)\end{array}$ & $\begin{array}{l}0.024 \\
(0.017)\end{array}$ \\
\hline *I $\mathrm{I}(9-10$ carriers $)$ & & & $\begin{array}{l}0.021 \\
(0.019)\end{array}$ & $\begin{array}{l}0.023 \\
(0.019)\end{array}$ \\
\hline$* \mathrm{I}(>10$ carriers $)$ & & & $\begin{array}{l}-0.040^{*} \\
(0.022)\end{array}$ & $\begin{array}{l}-0.045^{* *} \\
(0.022)\end{array}$ \\
\hline Demographic Factor & $\begin{array}{l}0.415^{* * *} \\
(0.025)\end{array}$ & $\begin{array}{l}0.434 * * * \\
(0.026)\end{array}$ & $\begin{array}{c}0.414 * * * \\
(0.025)\end{array}$ & $\begin{array}{c}0.433 * * * \\
(0.026)\end{array}$ \\
\hline Plan Design & $\begin{array}{l}0.321^{* * *} \\
(0.005)\end{array}$ & $\begin{array}{l}0.321 * * * \\
(0.005)\end{array}$ & $\begin{array}{c}0.322 * * * \\
(0.005)\end{array}$ & $\begin{array}{c}0.321 * * * \\
(0.005)\end{array}$ \\
\hline Market-Year Interactions & $\mathrm{N}$ & $\mathrm{Y}$ & $\mathrm{N}$ & $\mathrm{Y}$ \\
\hline p-values from $\mathrm{H}_{0}: \gamma_{1,1}=\gamma_{1,5} \mathrm{H}_{1}: \gamma_{1,1}>\gamma_{1,5}$ & $\mathrm{~N} / \mathrm{A}$ & $\mathrm{N} / \mathrm{A}$ & .00 & .00 \\
\hline
\end{tabular}

$* \mathrm{p}<0.10, * * \mathrm{p}<0.05, * * * \mathrm{p}<0.01$

Notes: The unit of observation is the employer-market-year. Specifications correspond to equations (A3) and (A4) and are estimated by FGLS to account for serial correlation of errors among observations from the same employermarket. 